\title{
Ser desempregado para os sociólogos
}

\author{
Didier Demazière*
}

Ora, produz-se [...] um fenômeno notável: como fato econômico, a burguesia é nomeada sem dificuldade: o capitalismo se professa. Como fato político, ela se reconhece mal: não há partido "burguês" na Câmara. Como fato ideológico, ela desaparece completamente: a burguesia apagou seu nome passando do real à sua representação, do homem econômico ao homem mental: ela se atribui fatos, mas não compõe com os valores, ela submete seu estatuto a uma verdadeira operação de ex-nominação; a burguesia se define como a classe social que não quer ser nomeada. "Burguês", "pequeno-burguês", "capitalismo", "proletariado", são os pontos de uma hemorragia incessante: fora deles o sentido desaparece até que o nome se torne inútil.

(BARTHES, 1957, p. 211-212)

C

omo os sociólogos esmiúçam a categoria "desemprego" para analisar os desempregados? Para além dessa ancoragem temática, eu gostaria de delimitar as condições de desenvolvimento de análises empíricas do fenômeno da categorização social concentrando-me, sem julgamento de valor, no conceito de desemprego e excluindo qualquer outra grandeza ou propriedade. Ao enraizar a análise num campo particular, não pretendo adotar um ponto de vista sobrepujante sobre um domínio de pesquisas que me interessa, mas creio simplesmente encontrar, nessa opção, uma ilustração comprovadora e estimulante. Os conhecimentos acumulados sobre a condição de desempregado são importantes e mais preciosos ainda pelo fato de destinarem-se a leitores pouco concernidos pessoalmente pela experiência biográfica do desemprego. Eles permitiram

Sociólogo, pesquisador no CNRS, diretor do Laboratório PRINTEMPS (Université de Versailles em Saint Quentin Yvelines). Endereço eletrônico: didier.demaziere@printemps.uvsq.fr. 
melhor compreender as interpretações que os sujeitos privados de emprego faziam da experiência do desemprego. Minha hipótese é que as pesquisas sociológicas realizadas contribuíram para produzir análises racionais das maneiras de viver o desemprego, mas sem jamais enfrentar o problema, crucial a meu ver, dos mecanismos de definição dos desempregados, dos usos desta palavra identitária. Eu gostaria de argumentar inicialmente que a orientação maciça em direção ao estudo do vivido do desemprego contribuiu consideravelmente para distanciar as pesquisas sociológicas sobre os desempregados das problemáticas da categorização social ${ }^{1}$.

Não é fácil encontrar explicações para a frágil ancoragem teórica dessas pesquisas e para a timidez das teorizações decorrentes. Mas deve-se reconhecer que esse domínio praticamente não foi estruturado pelos debates conceituais da disciplina e sempre esteve marcado por um empirismo invasor. Uma tradição temática capaz de identificar uma "sociologia do desemprego" (DEMAZIÈRE, 1995a) não se constituiu, e o interesse pelo desemprego foi descontínuo, com uma inflação de pesquisas a partir de meados dos anos 1980, sob o impacto de uma demanda pública que fez eco à persistência da penúria de empregos (DEMAZIÈRE,1992c; GARRAUD, 2000).

Esses financiamentos contratuais pesaram de maneira muito direta sobre as orientações de pesquisa, por exemplo, com a progressão rápida do tema de avaliação das políticas públicas de luta contra o desemprego. Para completar as abordagens estatísticas, altamente dominantes e reservadas aos economistas, os sociólogos foram encarregados de analisar o vivido do desemprego. Tornaramse os especialistas desse vivido: os que fazem o trabalho de campo encontram os desempregados, entrevistam-nos, prestam conta daquilo que escutaram e viram. As diretrizes para a pesquisa estão aparentemente muito soltas e pouco diretivas, pois essa orientação valoriza o trabalho empírico e indutivo, delega ao pesquisador a condução de pesquisas qualitativas, atribui ao sociólogo um saber-

1 Extraído do livro: DEMAZIERE (2003). Le chômage: comment peut-on être chômeur? Cap. 6, «Être chômeur, pour les sociologues» (p. 215- 274). Texto traduzido por Bernardete Wrublewski Aued e Ione Ribeiro Valle. Revisado por Anne-Sophie de Pontbriand Vieira. 
fazer na forma de abordar as populações reputadas como difíceis e pouco loquazes, um pouco misteriosas e, porque não, inquietantes. Ao mesmo tempo em que a sociologia ganhava um espaço reconhecido e valorizado, mesmo sendo frequientemente considerado como menor em relação às abordagens quantitativas ou matemáticas, encontrava-se consignada e confinada nesse espaço, porque nenhum princípio de estruturação interna pôde corrigir e compensar essas diretivas externas. Ao contrário, se pudéssemos diagnosticar uma continuidade nas pesquisas sociológicas sobre o desemprego, ela diria respeito igualmente à análise das maneiras de viver essa experiência (DEMAZIÈRE, 1996); isso explica porque ela não se constituiu num contrapeso aos efeitos da encomenda pública de pesquisas.

Esta constatação significa que as problemáticas da categorização social não estiveram no centro de uma sociologia preocupada em compreender como os indivíduos revestem-se estatuto social de desempregado. Uma vez constituído esse estatuto, os indivíduos que o ocupam são considerados como desempregados, mesmo que interpretem diversamente sua situação. Mas essa situação está dada e, além de tudo, ela cria desempregados: o problema das modalidades de passagem de uma categoria estatutária à qualificação de situações individuais não é central, ao menos em uma primeira análise. Decerto os sociólogos afirmam que o desemprego não é somente uma condição econômica ou uma privação de emprego, e que ele implica um reconhecimento social, a atribuição desses traços a alguns indivíduos, a construção social de uma legitimidade para reivindicar um emprego, a definição de uma rede de direitos e obrigações recíprocas socialmente regradas. De certa forma, os sociólogos concordam em afirmar que o desemprego é um construto social, uma categoria elaborada.

Mas a análise das reações individuais e subjetivas a essa condição socialmente definida não leva necessariamente em conta a categorização social em si. Porque, geralmente, ela reconhece que os desempregados são produzidos pelo desemprego, que eles existem enquanto desempregados pela objetividade de uma condição de desocupação profissional, validada por um registro administrativo. Apesar disso, as operações de elaboração dessa categoria constituem, no meu entender, um objeto privilegiado para o sociólogo, 
ou ao menos uma dimensão da qual ele não pode se desviar, mesmo que seja depois de ter realçado sua importância. Isso remete à categorização dos desempregados como tais e não do desemprego propriamente dito, isto é, mais à definição das identidades do que à emergência de um estatuto, aos usos da palavra desemprego e de outros termos associados no mesmo universo semântico para definir situações concretas, à produção e à circulação de enunciados que servem para qualificar, re-qualificar, desqualificar pessoas.

Minha perspectiva não é de esboçar um panorama exaustivo das abordagens sociológicas do desemprego, mas de diferenciar posturas em face das categorizações dos desempregados: como os sociólogos constroem suas análises dos desempregados e que relações estabelecem com as categorias sociais, mais ou menos explicitamente, em seus procedimentos? Sob que ângulos eles estudam a experiência do desemprego? Considero assim as posturas relativas à experiência do desemprego, mas também os resultados produzidos e, por consequiência, as teses avançadas sobre o que constitui o cerne da condição de desempregado. Esses pontos de vista descrevem as várias maneiras de dizer o que são os desempregados, não numa busca do que compõe a essência do desemprego, porque, mais uma vez, o essencialismo não encontra eco no meio dos sociólogos, mas na procura do que contém a categoria desemprego, do que define as especificidades dessa experiência. Nesse sentido, toda análise do vivido, pois é disso que se trata, engaja uma relação, às vezes implícita e até não controlada, com as categorias sociais. Ela é também uma maneira de categorizar os desempregados, eventualmente por intermédio de um registro, analítico mas também social.

Distinguirei quatro formas de sentir a experiência do desemprego, que se assemelham a aplicações dos quatro métodos identificados anteriormente. Para defender esse ponto, me apoiarei na seleção de um pequeno número de pesquisas, consideradas como emblemáticas, porque deram ritmo às evoluções da análise sociológica do desemprego e caracterizam bastante tal ou tal postura típica. Apesar de centrar a demonstração nessas pesquisas de base, mobilizarei outros exemplos para aprofundar a análise de tal ou tal modo de categorização ou para mostrar a diversidade desses regimes. 


\section{Experiências unificadas e unívocas}

As primeiras pesquisas sociológicas que tomam explicitamente como objeto de estudo os desempregados foram realizadas no decorrer dos anos 1930. O contexto no qual essas investigações pioneiras foram desenvolvidas estava marcado pela progressão rápida das taxas de desemprego, pela amplitude das ondas de afastamentos, pela falência de numerosas empresas. Isso correspondeu às primeiras manifestações importantes, de um ponto de vista quantitativo, do desemprego no sentido moderno, isto é, de um desemprego que atingiu os trabalhadores urbanos que haviam adquirido estabilidade num emprego assalariado em tempo integral e para os quais o trabalho na fábrica era a atividade exclusiva. A partir daí, a privação de emprego impunha uma degradação brutal das condições de vida, dado o caráter embrionário dos sistemas de indenização. Ela implicava também a perda do estatuto de assalariado, que não podia ser compensado pelo recuo em outras atividades híbridas situadas na encruzilhada das relações mercantis, da autoprodução e da auto-subsistência, características dos modos de vida dos operários agrícolas.

Esses primeiros desempregados confrontaram-se então com um desemprego instituído- aparecendo como o oposto do emprego assalariado- mas também com um desemprego fragilmente enquadrado e pobremente protegido. Além do mais, foi para protestar contra as condições insuportáveis de vida que os desempregados participaram de várias marchas contra a fome e de revoltas contra a miséria (DEMAZIÈRE \& PIGNONI, 1998). Esse estado da formação do desemprego não explica somente as resistências coletivas como esclarece também as orientações teóricas e metodológicas dos sociólogos. Essas apresentam dois traços principais. O primeiro concerne ao caráter muito aprofundado de investigações empíricas que visam compreender como os desempregados vivem uma condição amplamente nova e inédita. O segundo, menos perceptível, remete ao fato de que a experiência do desemprego aparece como produto da interiorização de crenças coletivas em face do emprego e do trabalho. Ela é descrita como uniformemente negativa, desvalorizadora e humilhante. Essas características ressurgem sob 


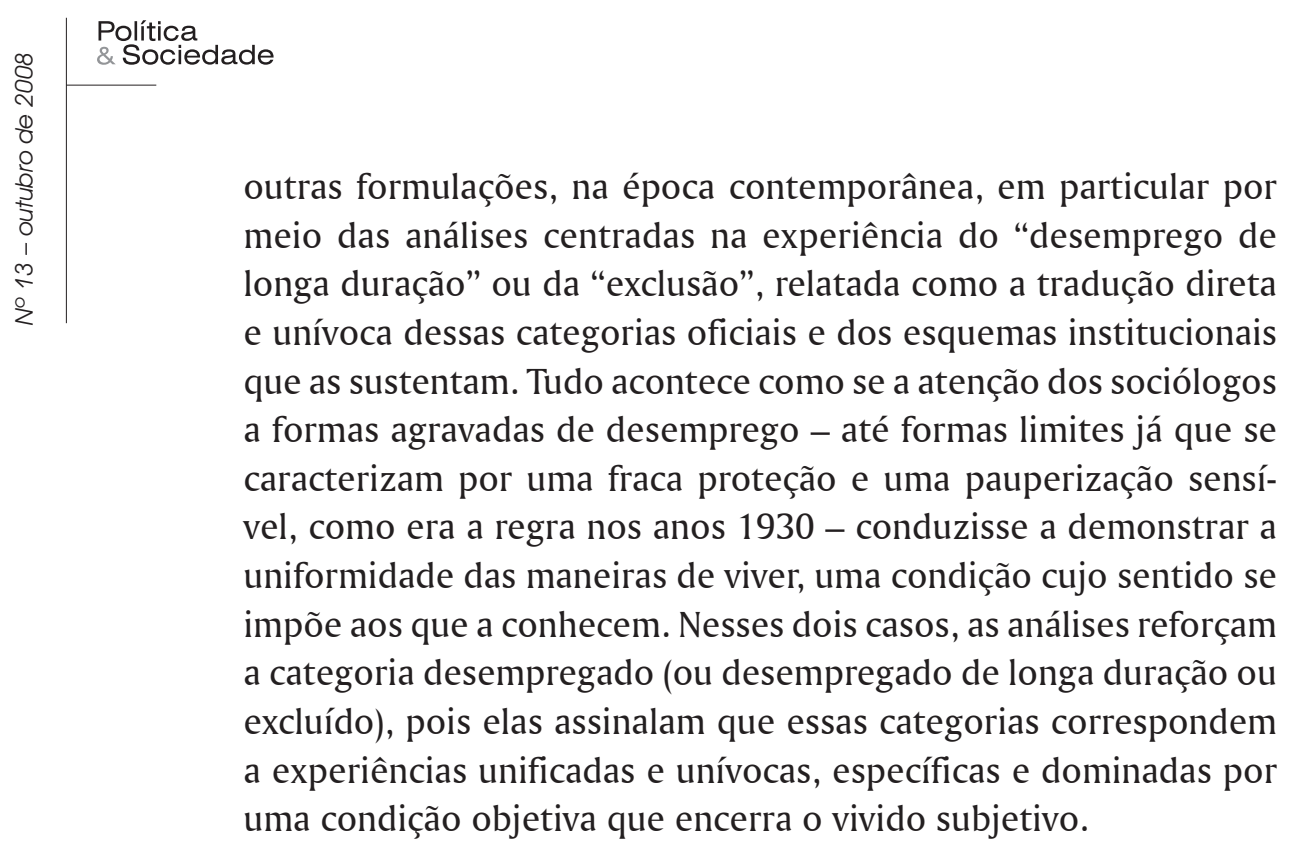

\subsection{Os desempregados em ruptura com a comunidade}

As pesquisas dos anos 1930 descrevem as consequiências sociais (psíquicas, econômicas, familiares...) do desemprego, apreciando o impacto da condição moderna do desemprego sobre os modos de vida. Essa condição é considerada como um fenômeno objetivo que se impõe ao sociólogo, mas também, com brutalidade, ao trabalhador e, portanto, convém medir seus efeitos principalmente quando eles são desastrosos. Mas, ao mesmo tempo, as abordagens sociológicas privilegiam uma sociografia voltada a apreender de maneira indutiva as consequiências do desemprego. O subtítulo original (em alemão) da pesquisa coletiva coordenada por Lazarsfeld, a mais célebre desse período, é sintomática desta postura: "Uma pesquisa sociográfica sobre os efeitos do desemprego de longa duração. Com um apêndice sobre a história da sociografia" (LAZARSFELD et alii, 1932). Essa perspectiva transparece no decorrer de todo o livro e tem por objetivo preencher o "vazio [...] entre as estatísticas oficiais e as impressões todas aleatórias da reportagem social" (idem, p. 23). Trata-se de ir e ver, de entrar em contato com a população, de descrever como ela reage ao desemprego, de compreender "a experiência do desemprego" (idem, p. 24). 
As circunstâncias nas quais essa pesquisa foi proposta e desenvolvida são igualmente esclarecedoras sobre a maneira pela qual o desemprego se impôs aos sociólogos como uma realidade incontornável, objetiva, bruta. A hostilidade encontrada por seu projeto de pesquisa sobre o tempo livre conduziu Lazarsfeld a aceitar a sugestão de estudar o desemprego. A anedota seguinte é descrita por Zeisel quase meio-século mais tarde:

"Em decorrência da sucessão imprevista de acontecimentos, nossa imersão no movimento socialista orienta em direção à pesquisa mais importante que conduzimos durante esses anos. Os sindicatos austríacos tinham acabado de obter a liberação da jornada de dez horas. Paul, estimulado pela leitura de estudos americanos, pensava que deveríamos fazer uma enquete sobre a maneira pela qual os trabalhadores utilizavam o tempo livre que acabaram de conquistar. Naquela época, tínhamos o privilégio de poder falar ocasionalmente de nossos projetos com Otto Bauer, o líder sábio e ascético do partido social-democrata. Quando Paul lhe falou de seu projeto, Bauer reagiu violentamente: que piada era essa de estudar os usos do tempo livre num país que sofria de um desemprego crônico que chegava a $10 \%$ ! O tempo livre que valia a pena ser estudado, disse ele, eram os efeitos sociais e psicológicos do desemprego de longa duração. Foi exatamente isso o que fizemos em Marienthal" (ZEISEL, 1979, p. 13).

Os efeitos sociais e psicológicos do desemprego; a fórmula condensa uma abordagem do desemprego que o vê como uma ameaça para as ligações sociais, que o vê como uma ruptura na vida social comunitária. É dessa forma que essa pesquisa estabelece as linhas de força que vão organizar os estudos posteriores conduzidos nos anos 1930.

Certamente, num contexto em que a indenização do desemprego é embrionária e frágil, as consequiências materiais do desemprego ocupam uma parte significativa da análise. As reconstituições minuciosas dos orçamentos das famílias, da estrutura de suas despesas, da evolução de suas compras, configuram o cenário preciso de uma pauperização que aparece com força e evidência. Mas a sociologia não considera o desemprego pelas privações materiais que ocasiona, pois se as relações entre desemprego e pobreza são 
notórias, os dois fenômenos são distintos: o desemprego é especificado por um fenômeno de privação relativa e, sobretudo, por uma destruição das relações sociais no seio da comunidade. A localidade de Marienthal corresponde a um tipo de caso-escola por tratar-se de uma pequena vila organizada em torno de uma fábrica que ritmava a economia e a vida social local: "Marienthal nasceu em torno de uma fábrica. A história dessa fábrica é a história da vila” (idem, p. 36). Desde meados do século XIX, um complexo industrial têxtil prospera nessa localidade, antes de conhecer dificuldades nos anos de 1920 e depois de fechar suas portas em 1931, precipitando ao desemprego uma parte importante da população masculina, mas também feminina. É por isso que o objetivo é estudar, como anuncia claramente o título da versão inglesa, uma "comunidade em desemprego".

A equipe de pesquisadores, que passa vários meses em Marienthal, combina métodos variados: coleta de documentos pessoais, estabelecimento dos orçamentos das famílias, relato dos cadastros de aluguéis, previsão orçamentária, inventário de refeições, participação em diferentes atividades coletivas etc. As entrevistas biográficas ocupam um lugar importante, como em outras pesquisas realizadas no mesmo momento na Inglaterra (BEALES LAMBERT, 1934) ou na Polônia (ZAWADSKI \& LAZARSFELD, 1935), pois sessenta e dois "relatos completos de vida" foram efetuados. Isso demonstra uma preocupação em apreender a experiência do desemprego a partir do ponto de vista dos desempregados, de uma postura indutiva, das categorias não oficiais ${ }^{2}$. Mas esses relatos são finalmente pouco utilizados na análise. Eles ocupam um lugar extremamente marginal na apresentação dos resultados, como se a condição de desempregado se caracterizasse por um vazio de significação, ou como se ela contivesse em si uma significação tão

2 Categorias não-oficiais é a tradução mais próxima daquela empregada pelo autor “categories indigènes". Ao consultar o autor sobre a dificuldade em manter a expressão original, propomos essa interpretação, que foi imediatamente aceita. Demazière esclareceu que a utilização de "categorias indígenas" quer significar algo parecido com o gesto de um etnólogo escutando os indígenas, isto é, estar atento, inclusive, às questões de linguagem, aparentemente banais. Categorias não-oficiais abrangem, portanto, tudo o que não contemplam as categorias institucionais ou não eruditas; e, por conseguinte, tudo aquilo que é expresso numa linguagem comum falada por pessoas comuns. (Nota das Tradutoras). 
potente que se impunha aos sujeitos eliminando todas as outras definições alternativas, como se as significações subjetivas não fossem apenas a substituição de uma significação objetiva que fazia do desemprego uma ameaça para a comunidade.

Entretanto, os resultados identificam "quatro comportamentos distintos" que diferenciam as famílias (idem, p. 88). A primeira classe é aquela das "famílias estáveis", caracterizadas pelos seguintes traços: "caprichosos, crianças bem cuidadas, sentimento de bem-estar, atividades, projetos e esperança no futuro, alegria de viver, persistência na busca de um trabalho". Em seguida vem a classe das "famílias resignadas" abrangidas pelos seguintes critérios: "falta de projetos, falta de relações com um futuro qualquer, falta de esperança, necessidades reduzidas ao mínimo possível não excedendo a organização da casa, mas a uma organização perfeitamente controlada, crianças cuidadas e, apesar de tudo, conserva o sentimento de bem-estar relativo". A terceira classe é aquela das "famílias desesperadas", definidas pelos seguintes atributos: organização da casa perfeitamente controlada e crianças cuidadas, "mas é necessário acrescentar a desesperança, a depressão, a falta de perspectivas, o sentimento de insignificância de todo esforço e, portanto, o abandono de toda procura por um emprego, de toda tentativa de melhorar a vida cotidiana e a comparação incessante com a situação anterior". Por último, as "famílias apáticas" (reunidas em certas passagens com as precedentes sob a expressão "famílias dissolvidas") se distinguem das outras pelos seguintes elementos: "a casa e as crianças não são cuidadas, o ambiente não é desesperador, mas indolente. Não há projetos, a esperança está ausente, o capricho é irracional e não mais guiado pela satisfação das necessidades vitais [...], a família mostra sinais de desorganização, briga muito, mendiga e rouba algumas vezes. Não se faz nenhum projeto, mesmo para os dias e horas seguintes. Gasta-se o dinheiro do auxílio de alocação ${ }^{3}$ em poucos dias sem pensar no que vai acontecer em seguida".

Esta tipologia dá conta de comportamentos e de condutas mais do que de interpretações ou crenças. Ela apóia-se numa análise

3 Auxílio público mensal concedido às famílias visando completar o preço do aluguel. (N.T.). 
quase etológica ${ }^{4}$ dos desempregados, alimentada pelas observações nos alojamentos e nas famílias. Mas os pontos de vista das pessoas desempregadas não são mobilizados, menos ainda, suas maneiras de explicitar oralmente as suas experiências. Se esta classificação é ordenada a partir de múltiplos critérios, ela combina-os numa lógica unidimensional, que situa cada classe numa ordem hierárquica.

"Nós distinguimos diversos tipos de atitudes: uma atitude mais ativa, mais confiante que a categoria representativa dos resignados, e duas outras atitudes, mais humilhantes e desesperadas. Mas nós, finalmente, supomos não se tratar de estados sucessivos de um declínio psíquico, paralelo à redução dos recursos e das reservas" (idem, p. 129).

A diferenciação dos tipos parece fundada numa norma implícita correspondente ao comportamento ideal que a sociedade espera de seus membros, o qual é perturbado pelo desemprego com uma intensidade e uma rapidez variáveis. A tipologia visa à descrição das ameaças representadas pelo desemprego sobre a coesão da comunidade. Suas classes aparecem também como os estados sucessivos de um processo de declínio - como as publicações posteriores precisarão claramente (EISENBERG \& LAZARSFELD, 1938) -, que são também os estados de um processo de destruição das relações sociais.

Esses resultados ensinam que, pesando sobre as condutas individuais, o desemprego modifica as formas da vida social. Esta conclusão central pode ser desenvolvida, puxando, por exemplo, o fio da desestruturação do tempo - pois é a questão do uso do tempo livre que está na origem da enquete conduzida em Marienthal -, que conduz ao relaxamento das relações intersubjetivas e à degradação da coesão social. A temporalidade dominante nesta localidade é determinada pelos ritmos da fábrica, que ordenam as atividades dos operários. O desemprego provoca então uma desorganização dos ritmos sociais e das referências temporais: os desempregados se sentem desorientados e perdidos, eles não sabem o que fazer. Os homens mais que as mulheres - porque para elas o trabalho doméstico preenche uma parte da jornada - não chegam sequer a

4 Relativo à etologia, isto é, ao tratado dos costumes, usos e caracteres humanos. (N.T.). 
contar o que fazem durante o dia, não sabem dizer o que fazem, não conseguem nem mesmo dizer como sua vida cotidiana está organizada, lhe dar um sentido, uma orientação, uma significação. A experiência do desemprego, compreendendo os aspectos mais concretos e familiares da vida cotidiana, é indizível, pois os desempregados (sobretudo os homens) não chegam a enumerar cronologicamente num diário de bordo jornalístico, o que os sociólogos lhes haviam pedido para preencher, as principais atividades que haviam realizado. Nesse sentido, o desemprego impõe muito fortemente sua marca aos operários, que acabam perdendo o estatuto de sujeito falante. O desemprego não aparece como susceptível de ser categorizado pelos próprios desempregados, que são instrumentos passivos, remetidos a uma inatividade total, a uma vacuidade que invade suas existências, e mesmo a um silêncio absoluto.

Vale a pena prever as consequiências disso sobre as relações no centro da comunidade. As atividades coletivas diminuem progressivamente, quer se trate da participação nas organizações políticas ou militantes, dos lazeres, da frequiência aos cafés e outros lugares de encontro. $\mathrm{O}$ desemprego conduz ao fechamento em si mesmo, à perda do espírito de iniciativa, ao abandono dos engajamentos em direção a outrem, ao enfraquecimento das cooperações, ao relaxamento da solidariedade: ele conduz a apatia. Pior, os pesquisadores levantam os sinais de degeneração das relações sociais: as práticas de "se virar", de "dar um jeito" são denunciadas às autoridades, o que pode provocar o corte dos benefícios obtidos junto às alocações pelos seguintes motivos: "um operário ajudou a cortar árvores em troca de certa quantidade de lenha; uma mulher entregou parte do leite que poderia ter conservado para suas crianças; um homem ganhou dinheiro tocando harmônica” (idem, p. 45). Assim, para o controle administrativo praticado pelas autoridades que decidem sobre a atribuição das alocações de desemprego, acresce o cortejo das denúncias de atividades que visam meios pecuniários suplementares. Os pesquisadores dedicam-se a distinguir os casos bem fundamentados desses "bicos" e aqueles que são mentirosos. Eles vêem nessas denúncias, principalmente quando elas são falsas, o sinal de uma degradação indubitável e profunda das relações sociais. Numa comunidade marcada pelo desemprego duradouro, 
dominam uma retração das relações, uma redução das atividades e um fechamento em si mesmo. A comunidade torna-se uma "comunidade largada", uma "comunidade extenuada".

Outras pesquisas que no mesmo período dedicam-se a descrever os efeitos do desemprego chegam a resultados amplamente convergentes: os desempregados curvam-se sobre si mesmos e distanciam-se da vida social mesmo quando vivem em uma "comunidade de homens trabalhadores" (BAKKE, 1940), as relações no seio da família deterioram-se (KOMAROVSKY, 1940), as denúncias dos outros às autoridades são freqüientes (BAKKE, 1933; ORWELL, 1937), a adesão dos desempregados aos valores estabelecidos enfraquece e os riscos de "decadência moral" aumentam (PILGRIM TRUST, 1938). Os balanços das pesquisas sobre os efeitos do desemprego durante os anos de 1930 (EISENBERG \& LAZARSFELD, 1939; JAHODA, 1979; HYMAN, 1979) sublinham que o desemprego sem dúvida conduz ao fechamento dos indivíduos em seu próprio vazio e à desestruturação das coletividades humanas.

Se essas pesquisas dedicam-se a descrever o mais próximo possível do cotidiano os modos de vida dos desempregados, elas insistem sobre a experiência comunitária mais que sobre as variações. Se elas tentam compreender como os desempregados vivem sua situação, acabam concluindo que há dificuldades em dar sentido a uma condição que funciona como um rolo compressor sobre as significações subjetivas. Isso quer dizer que a experiência do desemprego tende à homogeneidade, ou que a condição de desempregado impõe, mais ou menos rapidamente de acordo com os casos, uma significação única ou típica. Isto quer dizer também que essa significação comum é determinada pela perda de emprego e o prolongamento do desemprego, sem nenhuma possibilidade para as pessoas envolvidas de produzirem outras interpretações. A postura indutiva, e em todo caso empírica, que fundamenta essas pesquisas é esmagada pelo peso da categoria oficial de desemprego, e por uma postura teórica que define o desemprego como uma ameaça à comunidade, capaz de medir o impacto efetivo.

Finalmente esse grupo de abordagens, que atribui uma grande importância à análise dos efeitos psicológicos e pessoais do desemprego, mesmo que para apreender-lhes privilegie a observação 
exterior das condutas mais que a solicitação de uma reflexão introspectiva, tende a considerar os desempregados como uma categoria social particular, que se desligam das regras comuns de convivência e ameaçam, dessa maneira, a ordem social, formada por indivíduos que "vivem o fato de estar desempregados como um pertencimento a um grupo social específico" (LAZARSFELD et alii, 1932, p. 123). Esta postura, que faz dos desempregados um grupo à parte, não pode ser isolada de seu contexto histórico. Este corresponde aos primeiros momentos da formação de cortes importantes de ativos desocupados após haverem perdido um emprego assalariado, e às primeiras armas da categorização social dos desempregados: numerosos indivíduos são expulsos do seu emprego, que é também seu estatuto exclusivo, e muitos deles se apressam às portas dos organismos de indenização, em que são reconhecidos como desempregados, no sentido moderno, oficial (PUGLIESE, 1993, p. 55). Pela primeira vez o desemprego mistura-se no corpo social, encarna-se nos seres de carne e sangue, toma corpo nos cortejos visíveis diante dos escritórios de recolocação, às portas das fábricas, principalmente nas marchas contra a fome. Compreende-se que, em uma conjuntura histórica na qual a institucionalização do desemprego se torna realidade, isto é, traduz-se pela progressão rápida do número de desempregados, os sociólogos optaram por um procedimento indutivo visando apreender como os trabalhadores vivem o desemprego, para finalmente confirmar a categoria institucional que delimita uma população de desempregados como estando verdadeiramente à parte. As tentativas de descoberta das categorizações indígenas conduzem a retomada e mesmo a ampliação ou legitimação da categoria institucional. Mais surpreendente é o fato de que essa mesma relação com as categorizações reaparece no período contemporâneo em torno das formas mais exacerbadas de desemprego e, notadamente, de designação daqueles que aparecem como excluídos ou desempregados de longa duração.

\subsection{A síndrome da identidade negativa}

A categoria desemprego de longa duração se impõe na França e mais globalmente nos países do Ocidente, no decorrer dos anos 1980. Ela é lançada pelas instituições administrativas, gestoras de 
políticas do emprego e produtoras de estatísticas, estando apoiada numa idéia simples: a partir de certo tempo de desemprego, avaliado em termos probabilísticos e fixado convencionalmente em doze meses, as dificuldades particulares e suplementares (degradação das condições de existência, problemas de comportamento, problemas psicológicos, reticências de empregadores etc.) emergem ocasionando entraves ao acesso ao emprego (DEMAZIÈRE, 1995b). Essa categoria tem uma perspectiva operatória: ela serve para levantar uma fração de desempregados em condição de empregabilidade relativamente mais baixa, a fim de concentrar sobre este alvo um acompanhamento em direção ao emprego.

O processo que vai desencadear-se parece muito próximo do que ocorreu meio século antes: uma nova categoria oficial se impõe, os efetivos importantes foram identificados em conformidade com esta categoria, e uma demanda - comanda - social solicita às ciências sociais a análise da população assim designada. A partir de meados dos anos de 1980, os contratos de pesquisas consagrados aos designados como "desempregados de longa duração" se multiplicam. Uma apresentação sintética e racional de várias dessas enquetes sublinha o quanto os desempregados de longa duração compartilham a mesma "percepção subjetiva de suas situações", feita de sentimento de solidão, de aborrecimento, de auto-desvalorização, que conduz ao fechamento em si mesmo, à interrupção das relações com os outros, ao isolamento. Experiência estigmatizante, o desemprego de longa duração implica uma "identidade socialmente negativa", “ele não é em caso algum fonte de identidade” (PIGNONI, 1992, p. 296). Esses termos utilizados para restituir os efeitos do desemprego nos anos 1930 são empregados para identificar as consequiências do desemprego de longa duração nos anos 1990. Da mesma maneira que o desemprego era constituído como uma condição que impõe a todos que a viviam uma significação uniforme, o desemprego de longa duração é apresentado como uma experiência monolítica que imprime sua marca sobre as pessoas e que impede toda possibilidade de interpretação (de re- ou de contra-interpretação) da situação.

O desemprego de longa duração torna-se assim progressivamente uma categoria sociologicamente pertinente, por representar com mais força e verdade a experiência do desemprego: 
"A experiência dos desempregados de longa duração - significativa pelo seu caráter extremo - mostra que quanto maior for o tempo de desemprego, mais fraco se torna o peso das variáveis clássicas sobre a experiência, pois os desempregados conhecem de maneira uniforme a experiência do desemprego total, que exprime a verdade da condição do desempregado" (SCHNAPPER, 1994, p. 52).

O desemprego de longa duração não é apenas uma situação arbitrariamente circunscrita (doze meses de falta de trabalho), mas torna-se uma condição subjetiva apresentando uma significação homogênea, porque o prolongamento do desemprego uniformiza a experiência da privação de emprego. De categoria administrativa que designa um patamar convencional permitindo direcionar uma intervenção contra-seletiva sobre o mercado de trabalho, o desemprego de longa duração torna-se uma propriedade distintiva que permite caracterizar uma maneira de viver o desemprego, e por um tipo de ironia sociológica, desloca as enquetes empíricas orientadas para a descoberta dos pontos de vista indígenas. Um instrumento de enumeração concebido dentro de uma visão gestora torna-se uma identidade social ligada às pessoas que possuem o traço distintivo inicial.

O significado do desemprego de longa duração é dado (mas por quem?) e as pessoas que o vivem estão impregnadas (mas como?). A única resposta é que o sociólogo se tornou um pequeno alquimista das categorias sociais: as pesquisas dedicadas a apreender as maneiras pelas quais os sujeitos interpretam suas experiências, e que privilegiam um procedimento indutivo fundado notadamente na entrevista não-diretiva, chegam finalmente a atribuir a uma categoria oficial um conteúdo e um sentido que não tinha antes. Certamente se poderia imaginar que havia uma superposição de dois registros, oficial e indígena, de categorização, mas essa hipótese é bastante improvável. É mais pertinente sublinhar que a distância social entre os sociólogos e os desempregados, que é também uma proximidade dos primeiros com os postos de categorização institucional, engendra as dificuldades recorrentes para compreender os pontos de vista dos que conhecem o desemprego e a quem o sociólogo se dedica a escutar para categorizar as palavras suscitadas e coletadas: 
"O sotaque que eu tinha colocado nos trabalhos precedentes sobre a inferioridade do estatuto dos desempregados, sem sublinhar suficientemente o caráter relativamente positivo (mencionado anteriormente várias vezes), vinha de um etnocentrismo de funcionário reforçado pelas atitudes dos próprios desempregados: esses últimos analisam sua situação e sua experiência em função de estatutos superiores do emprego que aspiram, não dos estatutos inferiores desligados de toda referência ao emprego aos quais se esforçam para escapar" (SHNAPPER, 1989, p. 13).

O procedimento da pesquisa, consistindo em realizar entrevistas biográficas com os desempregados, para concluir em seguida que o desemprego é destruidor das identidades, é antigo e diz respeito em particular aos períodos marcados por uma forte institucionalização do desemprego. Os estudos empíricos de Ledrut nos anos 1960 ilustram-no bem, pois eles chegam a definir o desemprego como uma "queda de estatuto", vivida como uma verdadeira "decadência social", e afetada pelo estigma da "humilhação" (LEDRUT, 1966, p. 442). A humilhação do desempregado tem dois componentes. De uma parte, um "incômodo" social, isto é, o sentimento de ser mal considerado, de ocupar uma posição de pedinte, de se submeter a um tratamento que não merece, de ser confundido com bêbados ou preguiçosos. De outra parte, uma "vergonha" social, isto é, a impressão que se está à parte, o sentimento de culpa por aquilo que lhe acontece. Se o sentimento de humilhação ou de rebaixamento social é de intensidade variável, ele é "típico" das situações de desemprego (LEDRUT, 1961a, p. 63). O desemprego não se reduz então à privação de emprego ou a uma "inferioridade econômica", ele se define sociologicamente como "inferioridade social", ligada à desvalorização da posição de desempregado e à "impotência social" dos próprios desempregados, confrontados com o sentimento de humilhação, rejeitados em seu isolamento e reduzidos à paralisia coletiva. Esta acumulação define "a fraqueza social" dos desempregados, que tem tendência a funcionar como um círculo vicioso (LEDRUT, 1961b, p. 37).

O peso da categorização institucional na pesquisa sociológica fica ainda mais evidente com a invasão do campo do desemprego pela noção de exclusão, que tem uma história complexa e irregular (FRÉTIGNÉ, 1999, p. 51), ressurgindo na França nos anos 1990 em 
substituição àquela dos "novos pobres", para designar a acumulação de emprego, de isolamento relacional e pontuar assim um agravamento das consequiências do desemprego, notadamente prolongado. Ela não está codificada em uma categoria administrativa e se presta em consequiência a usos não controlados e simplistas: quando se trata de interrogar sobre a definição do desemprego de longa duração, uma vez que as delimitações foram oficialmente postas, esta questão é absurda no que concerne à exclusão. Igualmente esta categoria de fronteiras frágeis "funciona em parte por um modo imaginário” (PAUGAM, 1996, p. 15). É por isso que muitos sociólogos se esforçam para distanciar-se e raciocinar em termos de processo de exclusão, porque o "risco, quando se fala, por exemplo, de exclusão, consiste em constituir um estado que se proporia a tratar de si mesmo, enquanto esta é a ponta extrema de um processo em curso antes que as pessoas oscilem entre posições extremas" (CASTEL, 1992, p. 136). Mas também a vontade de prestar conta das condições de vida de populações marcadas por formas exacerbadas de desemprego pode conduzir, retomando de forma simplificada uma categoria oficial, a consolidá-la (WUHL, 1991, p. 92). Os quadros apresentados desses "excluídos" redobram aqueles desenhados a propósito de desempregados dos anos 1930. É sem dúvida porque as significações são simétricas, ou mais que isso, superpostas: nos dois casos trata-se de alertar sobre a ruptura das ligações sociais e sobre a dissolução da sociedade.

Falar de exclusão e mais ainda de excluídos, é reunir fenômenos heterogêneos numa mesma categoria, dando-lhes um nome que elimina essa diversidade. É finalmente reificar a categoria. A exclusão funciona, primeiramente, como uma categoria do discurso político, mais ou menos retomada pelos "peritos" para fornecer indicadores decorrentes de enquetes empíricas diversas (sobre os desempregados, os $\mathrm{SDF}^{5}$, os RMIstes ${ }^{6}$ por exemplo). Ela contribui

5 SDF: Sans domicile fixe: sem domicílio fixo. (N. T.)

6 RMI: Rendimento Mínimo de Inserção. [Vous pouvez bénéficier de l'allocation de revenu minimum d'insertion si : vous résidez en France, vous êtes âgé d'au moins 25 ans, ou vous êtes plus jeune et attendez alors un enfant ou assumez la charge d'un ou de plusieurs enfants, vos ressources sont inférieures au montant du RMI, vous concluez un contrat d'insertion.] Podem ser beneficiados pelo 
para compreender a gênese das evoluções em curso ou para antecipar os remédios eficazes? Esse é um debate que os sociólogos não se engajaram verdadeiramente: qual é a pertinência dessa categoria sem tradução objetiva clara e sem justificação objetiva atestada? (DEMAZIÈRE, 1993). A questão aponta duas diferenças em relação à situação do desemprego nos anos 1930: a exclusão não é nem uma categoria oficial dos institutos estatísticos ou dos aparelhos administrativos, nem uma categoria da palavra dos mais desprovidos de posses, quando o desemprego era uma categoria institucional mobilizada pela contagem e a gestão dos trabalhadores sem emprego e uma categoria indígena para alguns visando definir sua situação.

A utilização dessa categoria pelo sociólogo conduz inevitavelmente a privilegiar um ponto de vista sobreposto aos sujeitos que estuda, mesmo se há a preocupação de escutá-los e de recolher suas interpretações. Ela arrisca desembocar no retorno das rotulações substancialistas. Porque a retomada de categorias oficiais comporta sempre o risco de esmagar as categorizações indígenas, constituindo as populações designadas como um grupo à parte, um grupo pertinente, cuja pertinência não é interrogada. Em face desse perigo, não é suficiente rejeitar a tentação de fixar as categorias e de adotar uma definição relativa a um espaço-tempo social, como foi proposto a propósito das categorias de exclusão e de excluídos: "não é sensato querer encontrar uma definição justa, objetiva - e distinta do debate social - sem cair na armadilha da categorização de populações específicas, cujas fronteiras que as distinguem dos outros grupos sociais não são jamais claras. Querer definir o "excluído" em função de critérios precisos, válidos uma vez por todas, conduz, na realidade, a reificar categorias sociais novas ou similares àquelas construídas socialmente, e deixa entender que pode existir uma ciência de exclusão independente do contexto cultural específico de cada sociedade" (PAUGAM, 1966b, p. 565). Toda categoria social é relativa a um espaço-tempo social, é uma propriedade intrínseca. Por isso um uso categorial relativo a uma cultura equivale

RMI todos os residentes na França com mais de 25 anos, jovens grávidas ou responsáveis por uma ou mais crianças e aqueles que terminaram um contrato de inserção, desde que seus recursos sejam inferiores ao RMI. (N.T.) 
a uma definição objetiva e reificante. Para evitar essa armadilha, é necessário tomar esses usos por objeto e, por exemplo, comparar contextos societários diferenciados nos quais as categorizações, tanto as indígenas quanto as oficiais, de fenômenos com alguma semelhança têm todas as chances de serem heterogêneos.

O primeiro grupo de abordagem da experiência do desemprego atravessa a história das pesquisas sociológicas desde o desemprego dos anos 1930 até o desemprego de longa duração e à exclusão dos anos 1990. Ela parece emergir nos períodos em que uma categoria oficial instala-se e delimita uma condição, mostrando-se fortemente discriminante, mas também estigmatizante e desvalorizadora. Nessa conjuntura, o interesse pelas categorizações indígenas pode levar a uma retomada das categorias oficiais, porque as primeiras estão frequientemente implícitas ou porque decorrem do desconhecimento das perspectivas dos sociólogos, consideradas como dependentes das segundas. Então a população designada por elas parece efetivamente específica e pode mesmo ser descrita como um grupo à parte. O segundo caso constrói uma relação muito semelhante entre as duas ordens de categorias, mas privilegia as categorias oficiais, que esmagam as categorias comuns, produzindo uma análise bem diferente dos desempregados.

\section{Experiências ordenadas e objetivas}

O segundo tipo de análise empírica da experiência do desemprego apreende-a a partir de sua definição normativa: as dimensões consideradas como significativas correspondem aos critérios pertinentes para a categorização institucional. As perspectivas de acesso ao emprego, e notadamente a pesquisa de emprego e as atividades engajadas no mercado de trabalho, ocupam um lugar central. Nesse esquema de análise, o papel do desempregado, mais precisamente daquele que procura emprego, serve de referência, e as situações individuais são apreciadas em termos de distância à função. Essa postura de pesquisa afirma-se no decorrer dos anos 1960, num período em que a prosperidade econômica contribui para desfazer a dramática experiência do desemprego, tanto que esta passa a ser enquadrada por uma proteção social sólida. Mas 
ela não desaparece quando o desemprego cresce e as condições de indenização degradam-se, porque a questão da rapidez de acesso ao emprego e as estratégias individuais nessa competição são discutidas permanentemente.

\subsection{Uma quantidade de empregabilidade}

O objetivo principal da importante pesquisa realizada por Ledrut no início dos anos 1950 e 1960, período de baixo nível de desemprego, é analisar "o que são os desempregados" e descrever sua situação. Ora as enquetes que utilizam entrevistas do tipo clínico e questionários revelam a grande diversidade dos casos individuais, a dispersão das situações. Esse ponto de partida orienta sua reflexão no sentido de identificar critérios distintivos, definir princípios de inteligibilidade, diferenciar categorias de desempregados. Seguindo esse fio diretor, evocarei essa pesquisa desenvolvida entre dois pólos igualmente rejeitados, porque pouco satisfatórios para o conhecimento do desemprego e dos desempregados: a afirmação da unidade da situação que se aprofunda na figura do desempregado, isto é, do "desempregado tipo" e de uma "multiplicidade de variações que nenhuma lei permite compreender nos seus lugares e na sua ordem" (LEDRUT, 1966, p. 404).

Para evitar essa aporia, recorre-se a uma tipologia dedutiva que cruza duas noções consideradas como fundamentais: a "empregabilidade", medida pela duração de desemprego, e a "inferioridade", isto é, fatores que os tornam pouco atrativos na concorrência pelos empregos. Essas duas características estão parcialmente ligadas, porque uma grande inferioridade tem toda chance de conduzir a uma duração prolongada de desemprego. Mas elas não se sobrepõem porque, por exemplo, uma baixa empregabilidade não está obrigatoriamente relacionada a marcadores de inferioridade. Essas variáveis contínuas estão ordenadas em três grupos, cujas combinações dão seis tipos de desempregados (após a eliminação dos casos improváveis): desempregado pouco ou nada inferiorizado com um tempo curto de desemprego (inferior a um mês) chamado de "desempregado de transição", desempregado pouco ou não inferiorizado com um tempo médio de desemprego (entre um e seis 
meses) chamado de "desempregado de reserva", desempregado pouco ou não inferiorizado com um tempo longo de desemprego (superior a seis meses) chamado de "desempregado de depressão", desempregado mediamente inferiorizado com um tempo médio de desemprego chamado de "desempregado intermitente", desempregado mediamente inferiorizado com um tempo longo de desemprego chamado de "desempregado vulnerável", desempregado fortemente inferiorizado com um tempo longo de desemprego chamado de "desempregado crônico" (idem, p. 406-416).

Os tipos extremos são considerados como "formas limites de desemprego", em oposição às "formas fortes" (idem, p. 408): o primeiro porque está apenas desempregado, sendo que ele mantém sem dificuldade sua antecipação de um emprego; o segundo porque quase não é mais desempregado, sendo que ele tende a negar-se a trabalhar e resigna-se. Os tipos são hierarquizados segundo uma ordem correspondente a graus de proximidade em relação a uma concepção normativa do desemprego: os extremos estão situados fora desta norma, que exclui (ou distingue), por consequiência, desempregados que passam rapidamente por essa situação e desempregados que não chegam a abandonar o desemprego. Os desempregados dos quatro tipos intermediários estão todos igualmente desempregados, apesar das variações em sua empregabilidade e sua inferioridade. Mas os outros são menos desempregados que os desempregados, isso significa que a tipologia proposta contribui para precisar a categoria desempregado, separando certos casos do lado do emprego e outros do lado de uma posição parecida com a inatividade. Em nome de qual princípio? As variáveis escolhidas para construir a tipologia recorrem aos critérios que organizam a codificação institucional do desemprego, pois elas definem instâncias ao emprego. O raciocínio sociológico é claramente dedutivo, estando inscrito no quadro desenhado pelas categorizações oficiais, mesmo admitindose que as duas variáveis privilegiadas são "variáveis primárias", que “exprimem a situação de desemprego" (idem, p. 405).

Esses princípios de categorização dos desempregados podem ainda ser esclarecidos a partir de sua utilização no estudo da "procura de emprego" e da "vontade de trabalhar dos desempregados" (idem, p. 257). Esse eixo de análise de Ledrut é particularmente in- 
teressante porque coloca explicitamente a questão da categorização, argumentando sobre a necessidade de estabelecer diferenciações sociais e princípios de construção. Ele critica as posturas descritivas que se limitam a orientar os inventários dos comportamentos de procura de emprego a partir do levantamento de diferentes métodos ou modos de pesquisa. A perspectiva é passar da distribuição das intensidades de procura de emprego num continuum à distinção de graus, discretos, de atividades, ao recorte de categorias de desempregados em função dessas intensidades: porque é necessário "distinguir os ativos dos inativos", "é necessário saber quem é ativo e quem não o é, e por que” (idem, p. 258). Uma escala ordenada é então proposta comportando quatro classes: "móveis, ativos, semi-ativos, inativos ou passivos (nem esperança nem vontade)" (idem, p. 258).

Essa tipologia não é verdadeiramente resultado da pesquisa, mas um meio de estudar maneiras de viver o desemprego, deslocadas em relação à definição jurídica do desempregado. Assim, o último tipo é o objeto da análise: "uma classe que representa 39\% dos desempregados classificados. Esta proporção parece considerável quando se pensa que o desempregado é definido como o trabalhador sem emprego que quer trabalhar, que procura um emprego" (idem $\mathrm{P}$. 259). O objetivo é diferenciar os que não satisfazem as normas institucionais dos que "deixaram de ser 'verdadeiros desempregados', isto é, trabalhadores em busca de emprego” (idem, p. 259), que as enquetes anteriores não distinguiam. O caráter flutuante da nominação desta categoria ("inativos ou passivos, sem esperança, sem vontade") testemunha que ela constitui-se numa inovação proposta pelo sociólogo. Ela pode ser também o traço de uma construção frágil que mistura situações heterogêneas (espera da aposentadoria, dúvidas sobre as chances de encontrar um emprego, renúncia a procurar um, incapacidade para mantê-lo...), para dissolvê-las em uma nova categoria. A perspectiva seguida consiste em explicar esta "inatividade" ou "passividade", passando em revista muitos fatores possíveis: idade, duração do desemprego, doença, repetição dos fracassos, situação familiar etc.

Mas o levantamento, isto é, a fabricação de uma nova categoria de desempregados visa aumentar a pertinência da categoria oficial, medindo o funcionamento efetivo da imposição institucional 
e distinguindo os que decorrem dessa norma. A enquete aqui é um meio de afirmar a perspectiva do desemprego, mas na lógica da categorização oficial. Ela não está longe de propor uma revisão, pois os desempregados classificados no quarto tipo são caracterizados por uma ligação precária e ilegítima com o estatuto de desempregado e são renomeados: "eles adquirem um novo estatuto, esse de "pessoa assistida" para quem o auxílio ao desemprego constitui uma forma de socorro" (idem, p. 260), e, da mesma maneira, deixam de ser verdadeiramente desempregados, pois se distanciam das regras de conduta fixadas pelas instituições.

\subsection{Graus de mobilização e de autonomia}

O mesmo gênero de abordagem foi desenvolvido num outro contexto, marcado por um desemprego importante e persistente. O desemprego aqui não é considerado como uma condição social relativamente permanente, mas como uma transição no mercado do trabalho, e o sentido da experiência do desemprego é estudado a partir das tentativas para sair dessa situação. Ele é interrogado a partir das categorias oficiais, que definem o desempregado como alguém que busca emprego, apreende-o a partir da pesquisa de emprego, consigna-lhe a obrigação de procurar emprego. A circulação sobre o mercado de trabalho, em particular a triagem entre os postulantes ao emprego e os saídos do desemprego, orienta o olhar sociológico, que privilegia a procura de emprego como o componente mais significativo da experiência do desemprego.

Mas como descrever a procura de emprego? Geralmente, ela é apreendida a partir de nomenclaturas testadas e de codificações normalizadas, que distinguem uma variedade de meios mobilizáveis: recorrer às instituições, candidaturas espontâneas, solicitação de redes pessoais etc. (SIMONIN, 2000). Uma pesquisa qualitativa fundada nas entrevistas conduzidas junto de desempregados inscritos em uma agência local de emprego rompe com esta perspectiva, pois a procura de emprego é explorada a partir de relatos produzidos por desempregados (BENOIT-GUILBOT, 1990). Os indicadores escolhidos para descrever a busca de emprego não correspondem aos meios clássicos de pesquisa. A exploração dos materiais linguiísticos 
permite distinguir três dimensões da busca de emprego: o "grau de mobilização", o "grau de autonomia" e o "grau de flexibilidade". Esses critérios de classificação são originários das maneiras pelas quais os desempregados narram suas tentativas? Nada é tão certo porque nenhum extrato de entrevista foi mobilizado para argumentar a escolha dessas dimensões. Ao contrário, é a inovação das categorias oficiais que fornece a justificação, pois esta descrição dos comportamentos de procura de emprego recorre aos termos originários dos "debates políticos e sociais" e dos "imperativos ideológicos" correspondentes: "se mobilizar, responsabilizar-se por si e construir um projeto profissional” (idem, p. 494-5).

As combinações desses critérios permitem isolar três tipos de estratégias. Primeiramente os desempregados que têm "estratégias autônomas e/ou mobilizadas" multiplicam os procedimentos junto às empresas, recorrem à suas redes e negligenciam as instituições, porque contam apenas com eles mesmos para encontrar um emprego. Em seguida os desempregados que têm "estratégias desmobilizadas e dependentes" se desengajam porque estão desenganados e perderam a esperança de obter um emprego. Enfim os desempregados que têm "estratégias intermediárias medianamente mobilizadas" contam apenas com a ANPE $^{7}$ para acessar a um emprego ou se confrontam com dificuldades sociais que contrariam sua autonomia. Esta tipologia ordena as estratégias de busca de emprego, no objetivo de compreender seu impacto sobre o retorno ao emprego. O resultado obtido mostra que este é mais provável quando a autonomia e a mobilização são fortes, dependendo pouco da qualificação profissional e do nível de formação.

Essa pesquisa, que coloca em prática um dispositivo dedutivo a partir de entrevistas efetuadas com os desempregados sobre sua situação, mede finalmente o impacto das categorias oficiais sobre as pessoas desempregadas. Em efeito, a intensidade da mobilização e da autonomia traduz um grau de conformidade em relação às expectativas institucionais, cristalizadas no modelo do bom desempregado, visto como um procurador de emprego que interiorizou as expectativas normativas que pesam sobre os empregados, como

7 ANPE: Agência Nacional de Emprego. (N.T.) 
participantes da competição pela conquista de um emprego: "notase em efeito junto aos mais mobilizados e aos mais autônomos uma certa antecipação das exigências dos empregadores, que reforça a conformidade, ao menos formal, ao modelo dominante que os próprios empregadores assimilaram para serem bem-sucedidos e exigirem de seus assalariados" (idem, p. 505).

Apoiando a investigação sobre as categorias oficiais, este segundo grupo de abordagens estabelece que os comportamentos dos desempregados afastam-se, mais ou menos, da norma. Ele desenvolve-se num período de baixo desemprego, no qual as categorias oficiais estão solidamente estabelecidas e operantes, mas permanece quando a penúria de empregos agrava-se. Esta perspectiva, que compreende a experiência do desemprego a partir das categorias oficiais como se elas esfacelassem e aniquilassem as categorias não-oficiais, privilegia dois traços: essas experiências aparecem ordenadas em função de uma distância à norma do desempregado e ao emprego e objetivas, pois o sentido do desemprego é fornecido pelo programa institucional. A contrapartida desse esclarecimento é que as interpretações que os sujeitos produzem de sua situação são ignoradas, sendo apreendidas apenas como pura procura de emprego, ainda que ela seja inexistente. Por consequiência, não se pode compreender as eventuais re-interpretações e contra-interpretações produzidas pelos sujeitos, a não ser para lutar contra a perda de sentido associada a essas formas de desemprego, marcadas por um relaxamento ou, mais propriamente, por um abandono da procura de emprego. Esse é o campo do terceiro grupo de abordagens, que leva igualmente em conta as categorias oficiais, mas sem considerar que elas aniquilam as categorias não oficiais, procurando, nesse contexto, compreender as significações vividas pelos sujeitos.

\section{Experiências vividas e típicas}

O terceiro registro de análise da experiência do desemprego descreve-a a partir das significações subjetivas explicitadas pelas pessoas diretamente envolvidas. O sentido dessa condição é predefinido pelas instituições que o marcam muito fortemente, 


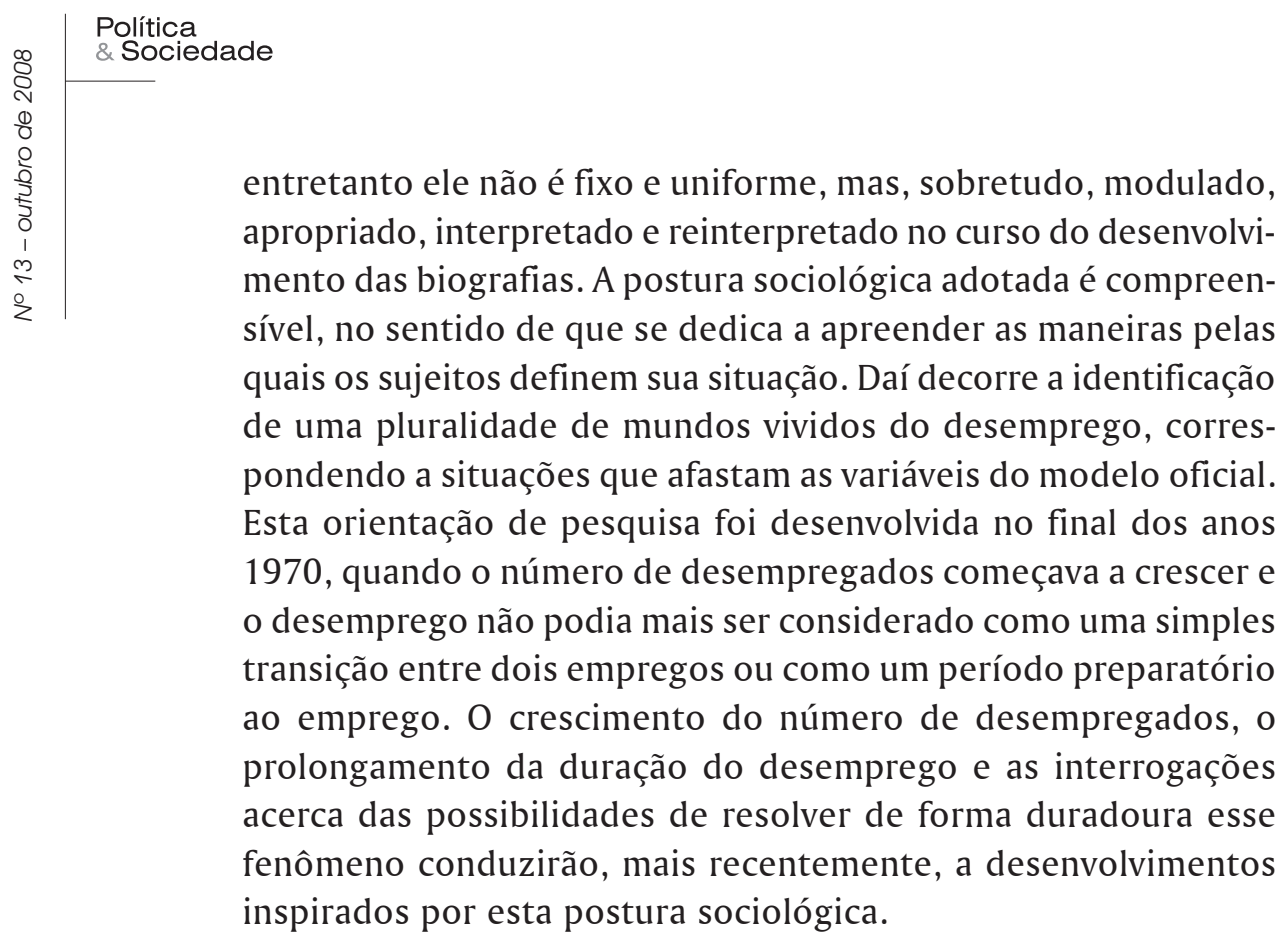

\subsection{Uma prova e suas interpretações}

A pesquisa realizada no final dos anos 1970 e consagrada à "provação do desemprego" (SCHNAPPER, 1994; 1999) representa um deslocamento da postura sociológica, pois se inscreve num procedimento compreensivo, estando atenta às significações subjetivas do desemprego e enraizada numa análise das maneiras pelas quais os sujeitos exprimem seus pontos de vista e explicitam em palavras suas experiências. Trata-se primeiramente de uma pesquisa de referência, primeiramente porque se situa concomitante ao longo período de elevado desemprego; a seguir porque é a primeira pesquisa de envergadura fundada no testemunho de desempregados, ainda que abordagens similares tenham sido realizadas junto aos trabalhadores licenciados econômicos ${ }^{8}$ (CHOMBART DE LAUWE, 1976; CUKROWICZ, 1981). Enfim, porque traça uma pista de análise muito utilizada em seguida principalmente para estudar o desemprego dos jovens e decodificar os "diferentes

8 Trabalhadores licenciados econômicos são todos os trabalhadores que foram mandados embora e que estão desempregados. 
vividos" (LE MOUËL, 1981), as "formas de experiência” (BALAZS, 1983), as "experiências de vida" (LAGRÉE, LEW FAI, 1989), as "realidades vividas" (PISSARD et alii, 1990).

O ponto de partida sublinha a consistência da condição de desempregado, que se diferencia claramente dos outros estatutos sociais, permitindo formular a hipótese de uma pluralidade de maneiras de viver essa situação. Numa sociedade em que a atividade profissional é o fator essencial de integração social, o pedestal da definição de estatutos sociais e o provedor principal do sentimento de dignidade (SCHNAPPER, 1997), o desemprego toma a forma de "provação", que subtrai os sujeitos da vida comum e normal. Assim os desempregados não participam mais da temporalidade dominante que alterna trabalho e não-trabalho, eles são confrontados à desorganização de seus hábitos, ameaçados pela desestabilização de sua identidade pessoal, conduzidos a interrogar-se sobre seu valor, invadidos pela inquietude em face de um futuro incerto. Se esses traços comuns, que foram sublinhados pelas pesquisas pioneiras dos anos 1930, definissem o desemprego, não seria suficiente descrever o que são os desempregados e suas reações a essa condição comum. Por isso "importa sublinhar a extrema variedade das condições de desempregado e as maneiras de viver o desemprego" (SCHNAPPER, 1994, p. 73). A exploração dessa diversidade apóia-se numa enquete por entrevistas aprofundadas e inspira-se numa postura compreensiva, dedicada a apreender o sentido vivido, as significações que os desempregados atribuem à sua situação. Trata-se de examinar como os desempregados negociam com uma categorização institucional que lhes é imposta, como se livram das margens de interpretação. Sem ocultar o fardo das imposições institucionais que pesam sobre eles (a pontuação na ANPE e o controle da procura de emprego, mas também a centralidade do valor trabalho ou, ainda, o olhar desvalorizador dos outros...), a pesquisa explora "as possibilidades que os indivíduos guardam de "brincar" com o sistema e de mobilizar seus recursos sociais a fim de reinterpretar os sentidos" (SCHNAPPER, 1999, p. 13). As entrevistas foram analisadas e reagrupadas em função dessas significações, e cada uma das proporções obtidas foi esquematizada em uma forma típica de experiência do desemprego. 
Três tipos são caracterizados, chamados "desemprego total", "desemprego invertido" e "desemprego diferenciado". Essa nominação não é insignificante. De começo, não falo dos adjetivos que visam condensar significações contrastantes de provação do desemprego, pois prefiro usar o termo desemprego que desempregado, indicando que a tipologia não classifica as pessoas, mas formaliza as relações subjetivas e sociais no desemprego. Voltarei a esse ponto mais tarde. Apresentarei primeiramente os três pólos desta tipologia, citando três curtas passagens de entrevistas extraídas de material abundante, para indicar a estreita relação entre os propósitos dos desempregados e a construção sociológica. A relação estreita entre as categorias não-oficiais e as categorias analíticas é em efeito uma especificidade exemplar - original para a época - dessa pesquisa.

Na forma do "desemprego total", o desemprego significa a perda do estatuto social procurado pelo emprego precedente, o fechamento em si mesmo, a ruptura das solidariedades anteriores. Os sentimentos exprimidos de maneira recorrente pelos desempregados compreendidos por esse tipo são a decadência, a humilhação, o aborrecimento generalizado, o vazio da existência, o medo do futuro. A figura do desemprego total delineia assim um mundo marcado pela marginalização social e pela falta de socialização, descrito e construído nos seguintes termos: "túmulo" (SCHNAPPER, 1994, p.100), "infelicidade”, "desvalorização, faltoso", "choque, iniquiidade, depressão nervosa”, "sempre com medo de ser confundido com um malandro", "eu sofro muito", "tinha vergonha de me apresentar [nas agências de desempregados]", "isso foi horrível”, "eu me aborreço, isso é evidente", "o que você quer que eu faça?", "isso me desencoraja, isso me desencoraja”, "isso é longo, isso é longo, isso é longo", "três quartos do tempo se reclama", "no fundo, é como se a gente não vivesse", "a gente gira um pouco no vazio", "atualmente eu quase não saio", "isso faz com que me feche em mim mesmo", "eu não vejo mais ninguém”, "o desemprego é qualquer coisa de mortal, hem, de mortal”, "a gente não é mais o chefe da família" (idem, p. 101-152).

A aversão em relação ao trabalho regular, rotineiro, executado sob a dependência de uma hierarquia, está no princípio de uma 
inversão do sentido do desemprego. Investir-se em atividades por si mesmo, engajar-se em paixões abandonadas até então, dedicar-se a práticas artísticas, adotar um ritmo de vida estudantil, constituem muitas variantes de investimento do tempo pelo desempregado. $\mathrm{O}$ "desemprego invertido" enraíza-se assim num sistema de valores, no qual o trabalho assalariado, imposto, tem um lugar secundário em relação às ocupações que fornecem ao indivíduo prazer e realização pessoal. Essa relação com o desemprego é exprimida nos seguintes termos: "eu sou, sobretudo, uma desempregada revelada", "eu aproveito ao máximo", "para mim o desemprego é férias", "eu não tenho tempo para me aborrecer", "os dias parecem terrivelmente curtos", "eu vejo muita gente", "eu jamais tive vontade de trabalhar 40 horas por semana”, "eu não pego qualquer coisa”, "eu trabalho por necessidade", "eu tenho mais amigos que antes", "eu não tenho vergonha, no sentido de inutilidade social”, "eu não me considero de fato como desempregada", "menos eu trabalho, melhor eu me porto", "eu tenho necessidade de criar", "o desemprego é paradisíaco", "é uma coisa que eu considero ser positiva” (idem, p.163-183).

Na experiência do "desemprego diferenciado", a procura de emprego constitui uma ocupação em tempo integral, um equivalente da atividade exercida no cenário do emprego. As modalidades de ocupação do tempo de desemprego são numerosas: procedimento de procura de emprego, participação em estágios para aperfeiçoar suas competências, engajamento em atividades para aumentar seus conhecimentos do mercado de trabalho etc., mas todas visam aumentar seus trunfos para a obtenção de um emprego. Essas atividades permitem resistir à desvalorização social e manter, apesar da privação de emprego, um estatuto de ativo. Eis alguns exemplos de fórmulas que ilustram esse terceiro tipo: "a gente trabalha ainda mais do que quando se trabalha realmente". "A busca de emprego [...] isso toma quase 20 horas das 24", "eu procuro... eu tenho muitos meios para procurar", "procuro aproveitar o tempo morto para adquirir outros conhecimentos", "sempre esse pensamento atrasado, enfim digamos, de encontrar trabalho", "a gente faz apenas um projeto, encontrar trabalho", "então eu jamais poderia fazer o estágio que eu faço agora”, "isso permite ver, fazer uma inquisição 
sobre si mesmo, o que a gente nunca tem tempo para fazer", "a preocupação, é sem dúvida ver também os amigos que podem nos informar", "atualmente eu vivo muito melhor minha condição de desemprego, porque eu acredito que é uma situação muito perigosa e vale mais retomar do que se arrombar", "eu acho que sou ao menos tão operacional quanto antes, graças os estágios que fiz e...", "eu frequientei durante 18 meses estágios diversos e variados, com formações práticas em empresas” (idem, p.194-232).

Esses tipos não classificam pessoas, mas descrevem mundos vividos do desemprego. No entanto a proximidade dos indivíduos com uma ou outra dessas significações não independe de características sociais. As variáveis que pesam sobre as maneiras pelas quais os desempregados categorizam sua situação são: o sexo, a idade e o pertencimento social (rendimento, nível cultural, profissão). Todavia, sua influência não é direta e determinante, de maneira que não se pode falar dum vivido do desemprego para as mulheres, para os jovens, para os operários etc. Essas variáveis agem por intermédio de três dimensões, consideradas como constitutivas da experiência do desemprego. A atitude de adotar atividades de substituição e de investimento num estatuto alternativo àquele do desempregado (aposentado, estudante, artista...) representa o centro da primeira dimensão. O desemprego será vivido mais positivamente quando o indivíduo consegue pôr em prática atividades definidas como vocação. A segunda dimensão é a intensidade e a forma de sociabilidade: quanto mais o desempregado está integrado a redes sociais independentes de sua atividade profissional, menos o desemprego será doloroso e penoso. Enfim a integração familiar constitui um suporte à crise de estatuto que é o desemprego, ao passo que as dificuldades familiares agravam essa crise de estatuto.

Essas dimensões designam diferentes recursos, financeiros, culturais, relacionais, sociais, simbólicos, os quais os desempregados dispõem em quantidade variável segundo sua posição social e sua trajetória biográfica. Em decorrência das desigualdades de distribuição desses recursos, cada tipo de desemprego aparece como experiência privilegiada de certos grupos. O desemprego total é maciçamente vivido pelos "trabalhadores manuais": sua ligação ao trabalho lhes expõe a uma grave crise de estatuto e lhes impede 
de adotar um novo estatuto ou de desenvolver redes relacionais independentes de seu trabalho. Ao contrário, os "jovens trabalhadores não-manuais”, maciçamente mulheres, conseguem inverter a experiência do desemprego, investindo-se em atividades ligadas ao estatuto de estudante ou de criação artística, desenvolvendo relações sociais independentes da atividade profissional. Enfim, são, sobretudo, os "executivos ou jovens contra-mestres ou técnicos em modalidade ascendente" que vivem a condição de desempregado de maneira diferenciada, multiplicando as atividades de formação, de procura de emprego e de lazer, e lutando assim contra a "desprofissionalização" e a "des-socialização".

Essa pesquisa não define tipos de desempregados, nem tipos de personalidade ou tipos de identidades: ela evita os riscos da rotulação das pessoas, levantando formas abstratas, diferenciando relações subjetivas a uma determinada situação. Ela procede pela análise do relato dos desempregados e apóia-se levando em consideração categorizações indígenas da situação. Estas variam em função dos atributos sociais dos locutores, mas, entretanto, elas são a cópia fiel de sua posição de pertencimento: se esse fosse o caso, as categorias não oficiais seriam reificadas e reduzidas a uma simples explicitação em palavras comuns das categorias oficiais impostas aos indivíduos.

Porém, duas interpretações da tipologia são possíveis, diferenciando-se do ponto de vista da análise da categorização. Segundo a primeira, a tipologia delineia um espaço de significações, abstratas, nas quais os sujeitos, concretos, podem circular em função das suas experiências: cada experiência contém um potencial de revisão das interpretações adquiridas e pode aproximar ou distanciar uma ou outra definição formalizada de maneira típica pelo sociólogo. Nesse caso, as mesmas pessoas podem, no decorrer do tempo, mudar de ponto de vista, adotar outra linha de conduta, revisar sua interpretação, mobilizar novas categorias.

De acordo com a segunda, a tipologia continua num espaço de significações abstratas, identificadas pelo pesquisador, mas este espaço é muito mais constrangedor para os sujeitos concretos confrontados com o desemprego: eles são abordados por uma alternativa que consiste tanto em submeter-se à provação do desemprego 
e interiorizar passivamente sua condição, quanto em reinterpretá-la ativamente para modificá-la ou, mais precisamente, para inverter seu sentido. Entretanto, as possibilidades de reinterpretação exigem muito mais. Não somente porque dependem de recursos mobilizáveis por cada um, mas, sobretudo, porque subsiste um sentido unívoco e objetivo do desemprego, "uma verdade bruta da condição de não-emprego [que] impõe-se aos mais necessitados" (SCHNAPPER, 1999, p. 88). O que é essa verdade e de onde ela vem? Ela é originária da modernidade ocidental e do "espírito do capitalismo", e mais precisamente dos valores coletivos que o caracterizam: a centralidade do trabalho desvaloriza os que dele estão privados. As categorizações indígenas são reações a uma categorização oficial, elas são colocadas à distância de uma significação invasora. Nesse caso, "as tipologias das maneiras de viver as provações sociais poderiam ser reduzidas a dois termos: a interiorização passiva de seu destino pelos indivíduos que os conduzem ao desamparo; a reinterpretação desse destino" (idem, p. 93). A força do destino força tanto mais implacável quando se aplica aos fracos, seria uma especificidade das "provações sociais", tais como o desemprego, a aposentadoria, o aprisionamento e, por que não, o divórcio, a perda de alguém próximo, a infecção pelo HIV etc.

Portanto, dá para perceber que a qualificação do desemprego como uma "provação" já é uma categorização, ainda que analítica e herdada de pesquisas anteriores como aquela conduzida em Marienthal. Em efeito, ela descreve uma maneira normal e normalizada de viver o desemprego, definida para os sujeitos que se encontram nessa situação, e que a interiorizam ou a redefinem. Esse postulado dá prioridade às categorias institucionais, ainda que para proceder a uma análise séria das entrevistas realizadas com desempregados. Ora, se comparar-se o desemprego com a aposentadoria e o aprisionamento pode-se destacar mais as diferenças que os pontos em comum: a especificidade do desemprego, parece-me, é o fato que seu termo é indeterminado, que sua saída depende da trajetória passada, mas também das transações com outrem, que o futuro está marcado por uma incerteza específica. Desde então, por que considerar o desemprego como uma provação, cuja forma pura é o "desemprego total" mais que uma competição, na qual a procura de 
emprego ocupa uma posição central, pois se constitui em objeto de injunções tirânicas da parte das instituições e mesmo dos próximos, e é o lugar onde se define continuamente o futuro? Se há um destino do desemprego é aquele do desemprego total e do desamparo ou aquele da procura de emprego e da mobilização (do desemprego diferenciado de qualquer tipo)? Sem dúvida, nem um nem outro, basta recordarmos que as categorizações oficiais do desemprego estendem-se entre os pólos da exclusão e da empregabilidade e que os desempregados são pegos continuamente em julgamentos que podem tanto desqualificá-los quanto qualificá-los.

O que está em jogo nessas questões é a articulação entre categorias oficiais e categorias não oficiais e, mais exatamente, a autonomia destas em relação àquelas. Segundo o que se considera ser a imposição institucional, sejam quais forem as formas, muito constrangedora ou pouco operante, se conceberá as categorias não-oficiais, como adaptações, seja sobre o modo da inversão ou como criações de sentidos. É precisamente essa questão que está subjacente às pistas de interpretação da tipologia das experiências vividas do desemprego. Mas para delimitar, isto é, para precisar o estatuto epistemológico e teórico das categorias não oficiais, é necessário passar por uma análise, tão precisa e séria, das categorias oficiais e de suas transformações. É isso que tentei esboçar nos capítulos iniciais deste trabalho, a fim de permitir-me adiantar que as categorias não-oficiais expressam vários jogos de linguagem. Mas antes de explorar como essa abordagem pode ser traduzida no campo do desemprego, discutirei outra pesquisa que considera igualmente a experiência do desemprego em termos de (re-) interpretações subjetivas dessa condição, sem, todavia, apoiar-se numa análise rigorosa dos relatos dos desempregados.

\subsection{A capacidade de criar alternativas e a contra- verdade}

Um segundo exemplo de pesquisa centrada no sentido vivido do desemprego pode ser abordado, porque esta análise é efetuada 20 anos após a precedente, enquanto o desemprego está duravelmente instalado na sociedade francesa, e é reveladora de outro 
estado do debate social, marcado por interrogações sobre o recuo do valor trabalho, às vezes formulado como uma possível "abolição do trabalho". Trata-se de uma pesquisa recente, consagrada à "vida cotidiana dos jovens desempregados" (SCHEHR, 1999). Esta é suficientemente emblemática de numerosas análises sociológicas centradas em populações vistas como excluídas, marginalizadas, dominadas, que priorizam a compreensão das significações vividas pelos sujeitos: privilegiar um ponto de vista indígena (ou não-oficial) é contestar as categorias oficiais, que desvalorizam essas populações silenciosas, e ainda criticar as abordagens sociológicas que alimentam essa visão exterior e sobrepujante; às vezes é também reabilitar grupos estigmatizados. Essas perspectivas resumem o projeto da sociografia dos jovens confrontados com o desemprego e com a precariedade: trata-se de priorizar as abordagens empíricas de campo e de criticar duramente as perspectivas "miserabilistas 9 ", e "trabalhistas 10", dominantes tanto nas instituições como nas sociologias dos desempregados.

Em primeiro lugar, trata-se de denunciar o que chamei de síndrome da identidade negativa, mas o argumento não é o mesmo aplicado na perspectiva compreensiva precedente: não seria suficiente ver nele uma tese abusiva negligenciando as capacidades que têm os sujeitos de reinterpretar sua condição; conviria ver também nele a consequiência das orientações normativas e dos sistemas de valores dos sociólogos. Fascinados pelo trabalho, no qual vêem o vetor principal da construção das identidades sociais e o cimento da sociedade, eles definem os desempregados, indiretamente, pelo que não têm (eles não têm emprego), não fazem (eles não trabalham), não são (eles não são produtores assalariados), por "artefatos trabalhistas" (idem, p. 15). A experiência do desemprego é então cercada pelo acúmulo de desvantagens, pela espiral da exclusão, a perda de estatuto, a ameaça de desfiliação, a vacuidade do tempo, pelo fatalismo generalizado, tantos traços que desenham um retrato "sociologicamente correto" (idem, p. 8) do desempregado, tantas

9 Miserabilista: Complacente na descrição da inevitabilidade da tragédia humana. (Nota da Revisora)

10 Trabalhista: a favor da empregabilidade indiscriminada. (N.R.) 
características denunciadas como evidências de senso comum, ainda que construídas e veiculadas por sociólogos.

O procedimento adotado pretende, "assumir o ponto de vista do instituinte" (idem, p. 28), rompendo com a definição institucional do desemprego (inscrição na ANPE como solicitante de emprego e norma da procura de emprego), para pôr o desempregado no centro da análise. Porque são os próprios desempregados que não aceitam ser definidos por categorias vividas como exteriores, percebidas como reducionistas, consideradas como inautênticas. Apesar da identidade do desempregado existir realmente como programa institucional, aqueles que são chamados de desempregados e a quem esta identidade é atribuída a rejeitam, assim como recusam "mais amplamente [...] toda tentativa alógena visando relatar - de uma vez por todas - o que eles fazem e o que são" (SCHEHR, 2000, p. 51). Esta pesquisa tira de uma concepção da sociedade contemporânea, que estaria marcada por uma individualização crescente das relações sociais e das carreiras, uma individualização tão acusada que se torna uma “diferenciação 'absoluta', isto é, [uma] singularização das trajetórias e das biografias” (SCHEHR, 2000, p. 50). Desde então não são somente os papéis e as afiliações herdadas que são desestabilizadas, mas também todas as categorias sociais, que se dissolvem num processo geral de (des-) categorização. As categorias desaparecem, ou ao menos perdem toda sua pertinência, porque os sujeitos recusam-nas e passam seu tempo fugindo delas. A tese é que em uma sociedade diferenciada, cujos membros passam de círculos em círculos, as categorias perderam toda aderência e toda coerência. A categorização desapareceu para dar lugar à singularidade das biografias. $\mathrm{O}$ problema é que a categorização é considerada como um processo homogêneo e monolítico: ela é concebida como uma classificação imposta das pessoas, que não se encontrariam nas caixas nas quais estão guardadas (pelas instituições e pelos sociólogos), mas não é considerada como uma estrutura cognitiva e social de base, como um elemento que estrutura qualquer interação. O que está acontecendo no plano empírico e como são analisadas as experiências do desemprego de jovens que recusam todas as atribuições?

A pesquisa de campo é, logicamente, direcionada para levar em conta as maneiras pelas quais os desempregados se autodefi- 
nem, as "formalizações vernaculares" (SCHEHR, 1989, p. 14) de suas práticas, enfim as categorizações indígenas de suas experiências. Esta postura conduz o autor a descrever as práticas de consumo e de regulação dos rendimentos, as atividades culturais colocando em jogo uma realização pessoal, as sociabilidades e a integração em redes de ajuda mútua, os ritmos de vida e as temporalidades vividas, a construção das identidades e as formas de evitar rotulações. Esses desenvolvimentos visam mostrar que os jovens desempregados tomam distância da ética do trabalho, inventam e experimentam novos papéis sociais independentes e dissociados do assalariado, em síntese, que o desemprego "não é somente a experiência de uma forma de ostracismo: ele é também um verdadeiro laboratório do social onde a experimentação e a criação têm igualmente seu lugar" (idem, p. 184). Finalmente o desemprego é considerado como um "mundo social" caracterizado por uma atividade central: "as práticas de criação de alternativas" ou toda outra prática que permita viver a condição de não-emprego. O desempregado é então "toda pessoa que atravessa esse mundo social, independentemente do olhar que dirigem sobre ela as instituições" (idem, p. 33). O desemprego está assim desconectado dos estatutos sociais ("demandador de emprego", estagiário, assalariado precário, interino...) e liberado das categorizações jurídicas; o que abre perspectivas para uma sociologia compreensiva dessa situação.

Mas quais categorizações são então levantadas, utilizadas, valorizadas? Essa de "criar alternativas" predomina amplamente sobre as explicitações dos próprios desempregados ao se referirem à sua situação, provavelmente porque esta pesquisa não está suficientemente ancorada em materiais empíricos e repousa sobre uma hipótese global opressiva demais. Segundo essa hipótese, o desemprego caracteriza-se por atividades práticas desconectadas do emprego, atividades que definem o valor social dessa experiência e que o sociólogo deve situar no centro de sua investigação ao invés de ver nelas uma experiência negativa e desvalorizadora. Então, o sentido subjetivo das práticas (supostamente de criar alternativas) não é extraído metodicamente da análise dos materiais da linguagem, apesar da postura reivindicada inicialmente. A palavra dos jovens é mobilizada de maneira ilustrativa pela citação de partes 
escolhidas destinadas a apoiar o raciocínio do sociólogo. O sentido é construído pela seleção dos fragmentos e por sua integração numa teoria pré-existente às entrevistas realizadas. Na ausência de uma análise séria e argumentada das maneiras pelas quais os (quatro) jovens desempregados entrevistados categorizam, eles próprios, as suas experiências, as conclusões parecem muito categóricas, e até peremptórias: "não é por ociosidade e por falta de trabalho que os indivíduos em uma situação precária se engajam em algumas atividades ou alguns projetos, mas é precisamente porque eles estão ligados aos últimos que `recusam’ o trabalho” (idem, p. 191).

Finalmente a perspectiva compreensiva se esgota numa luta contra os "artefatos trabalhistas"; ela não leva suficientemente a sério as maneiras pelas quais os próprios desempregados definem sua situação e acaba desembocando em novas categorizações igualmente contestável: "cenobitismo" 11 , nomadismo, etc. Porque estas resultam menos da análise empírica que dos pressupostos que declinam a categoria inicial do "criar alternativas", e contribuem para transformar os desempregados em "heróis" (GRELL \& WÉRY, 1993) ou para glorificar sua identidade de "nômades". O valor heurístico reivindicado seria duplo: ele se apóia numa ruptura com a categorização implícita do desemprego como experiência negativa, da qual os sociólogos são as vítimas ou os cúmplices, e resiste a toda tentação de classificação das pessoas, à qual cedem muitos sociólogos quando produzem tipologias. Mas, isso significa confundir classificação e, portanto, rotulação ou reificação das pessoas e construção de uma tipologia indutiva referente a relações, a uma condição, a situações.

$\mathrm{O}$ distanciamento em relação às categorias oficiais, sobretudo a crítica e a rejeição da categoria desempregado, não orientou a pesquisa para a explicitação das maneiras nas quais os sujeitos interpretam sua situação e dão-lhe sentido. Ela leva, antes, a propor novas categorias, consideradas mais pertinentes para relatar a vida cotidiana das populações estudadas. Essas categorias não exprimem uma pluralidade de interpretações do desemprego nem descrevem as regras de transformação dessas interpretações. Elas delineiam de

11 Vem de cenobite, isto é, religioso que vivia em comunidade, nos primeiros séculos cristãos. (N. T.). 
preferência uma mudança radical do ponto de vista institucional, substituem a síndrome da identidade negativa pelo seu oposto, avançam a tese da demissão relativamente ao regime salarial, do desinteresse perante a sociedade assalariada e da abolição do trabalho. Elas não se livram, portanto, de categorias gerais e sobrepujantes, mesmo que essas sejam mais minoritárias que dominantes, mesmo que emitam uma contra-verdade de preferência à verdade oficial. No final das contas é o próprio sociólogo que se engajou no jogo das categorias, ao invés de analisar metodicamente como os sujeitos praticavam esse jogo. $\mathrm{O}$ procedimento parece então muito próximo da postura adotada pelos sociólogos na década de 1930, que inscreviam suas enquetes qualitativas junto aos desempregados num quadro categorial preliminar e abrangente, e que geravam um tipo de reificação dos desempregados expresso numa categoria cujo sentido era unívoco. É simplesmente esse sentido que mudou de direção, pois o período dos anos 1930 era de consolidação da categoria desemprego, enquanto o dos anos 1990 é caracterizado por sua dispersão. Isso mostra apesar de tudo os perigos de desvirtuamento que ameaçam toda abordagem sociológica centrada na análise das categorizações contínuas e plurais: uma postura compreensiva que não está suficientemente ancorada na materialidade dos atos de linguagem corre o risco de extrair significações distantes demais das palavras pronunciadas pelas pessoas comuns.

No projeto sociológico correspondente a esse terceiro grupo de abordagens da experiência do desemprego, as categorias oficiais delimitam um sentido normal e normatizado, amplamente mantido por uma rede fechada de instituições e de regras de conduta, mas elas não esgotam as categorias não-oficiais. Estas emergem num cenário fortemente forçado e controlado e introduzem distâncias de amplitude variável. Essas abordagens emergem quando o desemprego está instituído, mas também quando ele se propaga e diz respeito a populações mais heterogêneas, notadamente a partir do fim dos anos 1970, quando o perfil típico do desempregado (homem demitido por razões econômicas da indústria, chefe de família e com um percurso profissional estável) diversifica-se. A experiência do desemprego separa-se então da condição de desempregado e é apreendida como uma experiência plural, diversa e heterogênea. 
O interesse pelas categorizações não-oficiais situa-se sempre em contraponto às categorias oficiais, e as interpretações subjetivas aparecem como subversões mais ou menos radicais, cuja afirmação depende amplamente das fontes biográficas. Outra perspectiva consiste em começar pelas categorias não-oficiais para apreender as significações do desemprego como uma invenção permanente por meio dos jogos de linguagem.

\section{As experiências variáveis e situadas}

Num quarto procedimento, a condição de desempregado é analisada por intermédio dos processos, contínuos e polêmicos, de produção do sentido e a partir da explicitação dessa experiência, tanto pelos sujeitos envolvidos em primeira pessoa quanto por "outrem significativo". Bem entendido as significações atribuídas a esta categoria são plurais, mas essa diversidade não é interpretada em termos de distanciamento em relação às categorias oficiais, porque são desestabilizadas e incertas. Segundo essa hipótese, os desempregados não dispõem mais de categorias prontas para interpretar sua situação e é necessário inventar significações, que são fluídas e polissêmicas. Resulta que a categorização deve ser estudada a partir de jogos de linguagem que se constroem nas situações de interação e de interlocução. As análises empíricas que fundamentaram esta via desenvolveram-se no curso dos anos 1990, quando as manifestações do desemprego endureceram, gerando um prolongamento da privação de emprego e uma pauperização dos desempregados. Essas manifestações contemporâneas do desemprego contribuíram para a desestabilização da categoria desemprego. Porque, paradoxalmente, foi quando o desemprego tornou-se mais evidente e mais duro que as fronteiras da categoria desempregado tornaram-se mais problemáticas e fluídas. Por outro lado, esses estudos empíricos centraram-se num primeiro tempo em casos específicos, selecionados por razões teóricas (RAGIN, 1992, p. 8) e correspondem a configurações nas quais os jogos de linguagem são mais facilmente observáveis. Em seguida eles transformaram-se em objeto de tentativas de extensão a situações menos particulares. Para desenvolver esse ponto me apoiarei essencialmente em pesquisas que conduzi nos últimos anos. 


\subsection{Desempregado e não-desempregado: categorizações negociadas}

As relações entre as instituições, geralmente públicas, e sua clientela, geralmente chamada de usuários, tornaram-se objeto de numerosos estudos sociológicos no curso dos últimos anos. Isso é particularmente evidente para as instituições que intervêm no quadro das políticas sociais e de emprego, cujo alvo é formado de maneira não-exclusiva por populações consideradas em dificuldade, vítimas da crise: agências de emprego e desempregados de longa duração (DEMAZIÈRE, 1992a; RIFÄ̈, 1996), comissões locais de inserção e locatários do RMI ${ }^{12}$ (ASTIER, 1997), missões locais e jovens em inserção profissional (JELLAB, 1997), Caisse d'allocation familial et beneficiaires de prestations sociales ${ }^{13}$ e beneficiários de prestações sociais (DUBOIS, 1999). As perspectivas fornecidas por esses diferentes guichês são plurais. Certos pesquisadores privilegiam as análises das tensões que atravessam a atividade dos agentes administrativos de proximidade, outros estudam as coordenações entre segmentos institucionais que intervêm para tratar de dossiês individuais, outros centram-se nos contatos mistos que se estabelecem entre o profissional e o beneficiário ou tributário.

Mas, essas pesquisas têm em comum o fato de caracterizar os espaços da atividade desta "burocracia de rua" como lugares encastrados nos quadros jurídicos formais e apresentando regras administrativas explícitas. Elas consideram-nos paralelamente como espaços de produção de categorias, cujo funcionamento é irredutível ao emparelhamento de compartimentos e de casos, à aplicação de regulamentos e aplicação de nomenclaturas. Essa categorização é um processo de negociação e de ajuste entre os protagonistas da situação: profissional e usuário, representantes de diferentes administrações, a serviços da mesma organização, colegas pertencentes à mesma equipe etc. A hipótese subjacente, e às vezes implícita, é que as categorias administrativas que organizam as atividades dos

12 RMI: Rendimento Mínimo de Inserção. (N.T.).

13 Caixa de Alocação Familiar que mantém vários programas sociais de ajuda aluguel, ajuda férias, e vários tipos de pensão. (N.T). 
agentes do guichê são cada vez menos operantes: as articulações se distendem entre as definições oficiais dos problemas a tratar e as situações das pessoas recebidas, entre as missões institucionais e os contextos da atividade cotidiana. No caso do desemprego, as interações entre agentes da ANPE, encarregados da colocação e de ajudar no retorno ao emprego, e desempregados de longa duração em dificuldade de acesso ao emprego são reveladoras dessa falta de concordância. Mas estes podem também ser explorados a partir das relações entre esses mesmos conselheiros profissionais e os empregadores que depositam suas ofertas de emprego na ANPE. A categorização do emprego está, portanto, em jogo, e as exigências formuladas pelos segundos conduzem frequientemente os primeiros a produzir qualificações sobre a oferta de emprego, interrogando seu pertencimento ao gênero emprego: as condições contratuais são aceitáveis? A oferta corresponde a um emprego conveniente? A proposição integra os hábitos do setor? Em síntese, trata-se verdadeiramente de um emprego, de um verdadeiro emprego? (DELFINE \& DEMAZIÈRE, 2000).

No caso do desemprego de longa duração, esse não pode mais ser definido como um período transitório que se fecha em pouco tempo pela obtenção de um emprego. Do mesmo modo, o prolongamento da privação de emprego não pode ser considerado como um problema técnico de falta de empregabilidade, que poderia ser preenchido pela orientação para as prestações de ajuda ao emprego (um estágio de formação, um resultado profissional, a falta de uma oferta de emprego). A incerteza porta então sobre a definição do objeto de interação, sobre a qualificação dos que, na linguagem administrativa, são definidos como desempregados de longa duração: o que fazer com eles e, sobretudo, são eles verdadeiramente desempregados? Reconhecem-se como tal? Os guichês onde se realiza o trabalho cotidiano dos agentes da ANPE podem ser considerados como lugares privilegiados de gestão da perda de aderência e de adesão das categorias oficiais e, portanto, de observação de processos de categorização não-programada. É assim que me propus, articulando observações in loco e entrevistas cruzadas com os protagonistas, a estudar as experimentações de categorias emergentes, que permitiriam aos agentes institucionais caracterizar 
e diferenciar os desempregados de longa duração, possibilitandolhes a confirmação de suas próprias definições.

Desse ponto de vista, a interação é organizada em torno do encontro entre reivindicações feitas pelas pessoas convocadas e atribuições sustentadas pelos profissionais. A categorização indígena é produto da confrontação desses pontos de vista relativos à qualificação da situação de desemprego (de longa duração), ela é resultado do ajuste progressivo entre os dois parceiros, ela é a celebração de uma negociação, certamente desequilibrada, mas irredutível a uma simples rotulação imposta a um indivíduo passivo e dominado. Nesse processo, a explicitação em palavras da situação ocupa um lugar eminente, pois a significação deve ser produzida no curso da ação. Ela é incontornável, porque as categorias pré-codificadas são inoperantes ou insuficientes. Em efeito, as duas bordas que enquadram a codificação do desemprego não são tidas como pertinentes. Essa de procurador de emprego não é aceitável para o profissional confrontado com um interlocutor que é desempregado de longa duração, isto é, inferiorizado e distanciado do emprego, menos fora do que nas instituições oficiais, onde é constantemente desencorajado e não consegue justificar verdadeiramente um empenho na procura de emprego. Essa condição de excluído ou não-empregável não é suportável para o desempregado que não se reconhece numa designação tão desvalorizadora, menos fora do que pelo profissional que está isolado entre os registros técnico e ético.

Se a categoria desempregado de longa duração está legada aos interativos, ela abre, mais do que fecha, um espaço de categorização, porque, da mesma maneira que a dor crônica para o doente e o médico, quando o desemprego torna-se durável, apresenta-se como atividade problemática (BASZANGER, 1986). A situação não pode, portanto, ser decifrada e nomeada sem uma discussão, uma troca de palavras, para a produção de uma interpretação compreendida, senão partilhada. Os protagonistas devem engajar-se em um processo interativo de categorização, que permita explicitar a situação do (possível) desempregado. Eles procuram confrontar e ajustar seus pontos de vista, engajam uma negociação pouco previsível, constroem compromissos entre a maneira pela qual o desempregado se autodefine e aquela definida pelo agente. Para 
levantar as incertezas, eles utilizam recursos e índices variados, que lhes permitem precisar, pouco a pouco, a situação, suporte e objeto de seu encontro. $\mathrm{O}$ agente dispõe frequientemente de informações registradas no dossiê individual do desempregado, ou de notas tomadas por seus colegas durante as entrevistas precedentes. Pode-se também interpretar certos elementos da aparência física do desempregado, ou seus comportamentos cara a cara. O desempregado pode portar e exibir certos objetos: dossiê de procura de emprego, lista de cachês de empresa, atestados diversos etc. Na ausência de recursos para procedimentos de testes ou de avaliação, a atividade linguiística é um componente central de interação. Os atores recorrem a eles permanentemente para construir, contestar ou validar as significações desses índices. Os protagonistas apóiamse em dados fugazes, emitem suas interpretações, resistem, negociam, manipulam, criam, para produzir uma categoria social que dê conta da situação do desempregado. Como sua ação não pode ser de mudança da situação, por exemplo, através da passagem do desemprego ao emprego, a única resposta possível é re-categorizar, jogando com as palavras. É porque são discursivas, e não codificadas ou estabilizadas, que essas categorizações devem ser negociadas e validadas; na falta delas não teriam valor social.

O profissional deve "fazer uma idéia de si" na situação do desempregado, de maneira a poder propor respostas que lhe parecem, ao mesmo tempo, adaptadas às dificuldades levantadas, conformadas à sua ética profissional, coerentes com os regulamentos, aceitáveis pelo interesse que possuem. O desempregado deve expor uma interpretação de sua situação que seja ao mesmo tempo adequada aos seus próprios objetivos, aceitável em relação às regulamentações, convincente e confiável para salvar as aparências e obter prestações positivas. Analisei essas interações a partir de três sequiências temporais que mais ou menos as estruturam: a fase de abertura consistindo em formular o problema, isto é, a distância entre a definição codificada do desemprego e a situação individual; a fase intermediária, divisível em subsequiências, explora esta situação redefinindo o quadro de interação colocada a uma distancia progressiva das normas administrativas; enfim a fase de fechamento que é a da busca de uma saída aceitável pelas duas partes, mas tam- 
bém não contraditória em relação aos regulamentos oficiais. Meu objetivo não era estudar a distribuição da circulação da palavra e a organização da conversação, mas tratava-se de considerá-la como um lugar de raciocínios práticos. Mas uma atenção particular também foi dirigida aos argumentos trocados pelos protagonistas, e mais precisamente às categorias linguíísticas que cada um mobilizava para informar a situação do desempregado. A análise das entrevistas realizadas num segundo momento permitiu explicitar os esquemas de percepção e as seleções de signos sobre as quais apoiavam as qualificações em situação. Um exemplo permitirá compreender os procedimentos de seleção dos materiais linguiísticos recolhidos, até a nominação de uma forma típica, aqui, "a exclusão indubitável" (DEMAZIÈRE, 1992a, cap. 6-7; DEMAZIÈRE \& DUBAR, 1997, p. 63).

Desde o início do encontro com o agente da ANPE alguns desempregados adotam ostensivamente uma atitude de distância em face da situação, sem testemunhar nenhuma hostilidade ou desconfiança, mas manifestando que eles não têm nenhuma ilusão a respeito do interesse do encontro: eles não devolvem o questionário que lhes foi enviado, destinado a atualizar as informações sobre sua situação, ou devolvem-no sem ter preenchido, porque não têm "muitas esperanças", declarando-se convencidos de "não mais poder trabalhar". Eles marcam assim seu desligamento em face da categoria desempregado mais que da situação, em face das obrigações legais - de procura de emprego -, as quais são normalmente submetidas pelo profissional que os recebe. Ao contrário, com isso eles tentam estabelecer uma relação de conivência: "Eu fui obrigado a extrair o resultado, e o resultado de minhas buscas não é bom, é sem esperança”, "Nos fazem compreender que não vale à pena insistir", "Um colega de vocês disse-me: não adianta esperar”. Desenvolvendo uma definição de sua situação separada da relação com o desemprego, eles propõem uma tipificação, supondo constituir-se numa explicação das distâncias em relação à norma e uma justificação de seu afastamento em relação à função: "Para nós os velhos, é muito difícil, vocês sabem," "Com todos os meus problemas, eu deveria ser chamado de deficiente".

Simetricamente, há casos em que os agentes da ANPE selecionam alguns traços que consideram como suficientemente 
pertinentes para caracterizar a situação do desempregado, e que lhes fornecem uma categorização provisória. Alguns confiam antes mesmo do encontro "Já com seu dossiê, 53 anos e mais de quatro anos na agência. Eu sei, isso é uma missão impossível", "Meu colega notou: graves problemas de saúde. Eu vou ver em seguida se isso evoluiu". Alguns atributos, os "problemas de saúde" e os "problemas de idade", como eles os nomeiam, são considerados pelos agentes como obstáculos intransponíveis para a retomada de emprego. Eles funcionam como estigmas, porque ocultam todas as outras características individuais, sendo suficientes para qualificar as situações: "Seu problema é a idade, e isso nem ele nem nós, não se pode fazer nada contra", "Esse é um caso simples, que não sai de sua depressão". Esses atributos funcionam como traços essenciais que não podem ser corrigidos, pior ainda quando são estigmas corporais, que aderem à pele, que são indeléveis. Isso revela-se bem nas expressões que os agentes da ANPE utilizam entre si para designar os desempregados inscritos nos fichários, mas considerados como inaptos ao emprego, sem futuro e, portanto, fora de seu campo de ação: "solicitações mortas, o túmulo".

Do ponto de vista da expressão de linguagem das categorias, essa qualificação da situação tem propriedades interessantes. De um lado, ela não pode ser formulada pelo agente no "cara a cara": "O problema é que eu não posso dizer: escute, senhor, eu não tenho o poder de rejuvenescer-te, então adeus". O agente pode, certamente, tentar persuadir seu interlocutor de que ele não conseguirá jamais obter um emprego insistindo sobre os traços que o desacreditam, mas ele só pode fazê-lo a partir de meias palavras. E somente o desempregado pode explicitar sua própria condenação. Mas, de outro lado, a qualificação da situação deve ser objeto de uma troca, porque as propriedades pertinentes são contínuas (se é mais ou menos idoso, se tem problemas mais ou menos graves de saúde, visíveis, curáveis...) e seu sentido só estabiliza, provisoriamente, ao preço da descrição: ser idoso, isso é demais; estar doente, isso é demais; mas os limites devem ser traçados e negociados. Isso abre a possibilidade de contestações e de polêmicas: um agente pode recusar a reivindicação de um desempregado ("Escute todo mundo diz que sua idade põe problema. Eu creio que às vezes é verdade, mas não no seu caso; 
não se é velho aos 45 anos, isso não é verdade?") e, reciprocamente, um desempregado pode rejeitar a atribuição do agente ("Você sabe, eu não abaixo os braços, todos vocês me dizem a mesma coisa, mas eu penso que com 54 anos não se está acabado").

A interação é, portanto, um momento de confrontação e de ajuste dos pontos de vista dos participantes, conduzindo a compromissos se a situação for categorizada em termos compatíveis pelos protagonistas. Num exemplo privilegiado aqui, estes concordam com a falta de pertinência da categoria oficial em razão de estigmas incuráveis. As pessoas englobadas não são mais (não consideram-se mais e não são mais consideradas) como "desempregadas". Entretanto, na ausência de estatutos alternativos acessíveis, elas são (consideram-se e são consideradas) como desempregadas. A contradição não pode ser levantada e não há verdadeiramente um termo adequado para nomeá-la, ao menos uma palavra ou uma expressão reconhecidas e aceitas pelas partes. Assim, estas são conduzidas a arranjar perspectivas de futuro, correspondendo a um retorno às categorias oficiais, alternativas a de desempregado, mas para mais tarde: antecipação da aposentadoria e fim da vida ativa para os idosos, antecipação de um hipotético reconhecimento de uma desvantagem ou de uma invalidez para os mais doentes. $O$ processo de nominação não está, portanto, acabado e concluído. É por isso que propus a expressão "exclusão indubitável" para indicar que alguma coisa de indizível se alterava, consistindo em admitir que não haja nenhuma chance de retorno ao emprego, nenhuma outra solução na atividade, e mesmo nenhuma saída evidente para a inatividade, breve, nenhuma escapatória para a armadilha do desemprego.

Mais globalmente, a análise desembocou na identificação de quatro maneiras típicas de (re) definir a situação dos desempregados. Cada um desses tipos condensa uma nova categorização, que não suprime a categoria oficial de desempregado, mas que a condena, no contexto, como insuficiente e impertinente. Cada forma típica corresponde a uma maneira de resolver as contradições entre o que se considera serem os desempregados do ponto de vista das normas oficiais e o que são do ponto de vista dos protagonistas. Cada categorização é uma maneira específica de conciliar o con- 
traditório e de apreender o que é incompatível: ela significa que se é desempregado e não-desempregado ao mesmo tempo, que se é desempregado sem corresponder à definição institucional, que não se é desempregado sem poder entrar em correspondência com uma categoria estatutária alternativa. O primeiro tipo corresponde a uma "exclusão indubitável”: os desempregados são definidos e se definem por traços estigmatizantes e insuperáveis, mas que não lhes permitem obter o benefício de estatutos de substituição, tal como a aposentadoria, a invalidez, as necessidades especiais. Fora dessas alternativas improváveis, eles são condenados ao desemprego durável e definitivo, a uma exclusão indubitável. O segundo tipo corresponde a uma "reinserção possível": os desempregados são definidos e se definem por atributos que testemunham ao mesmo tempo seu engajamento na procura de emprego e certas insuficiências de empregabilidade. Apesar do insucesso recorrente de seus procedimentos, as perspectivas de reinserção profissional não parecem impossíveis, ao menos a meio termo. O terceiro tipo corresponde a uma "transição durável": os desempregados são definidos e se definem pela repetição de fracassos e de desilusões na sua busca de emprego e pela acumulação de dificuldades que degradam sua situação. Na ausência de soluções para esses problemas, as perspectivas de futuro são mantidas na incerteza de uma transição durável. O quarto tipo corresponde a uma "transgressão tolerada": os desempregados são definidos e se definem pela sua participação, de amplitude variável, em atividades de trabalho ilegal, interditadas e incompatíveis com o estatuto de desempregado. Na ausência de perspectivas de acesso a um emprego declarado, essas atividades são consideradas como um sinal de autonomia e de "se virar", sendo toleradas ainda que transgressivas.

A atenção entre definições contraditórias que organiza cada um desses tipos ilustra claramente as diferenças entre as categorizações institucionais e indígenas: enquanto as primeiras traçam os limites claros e determinantes, as segundas têm fronteiras incertas e fluídas. Colocando em evidência a produção negociada de categorias oficiais, esta pesquisa permite precisar algumas de suas propriedades. Elas não suprimem as categorias oficiais, pois as pessoas concernidas não perdem a qualidade de desempregado 


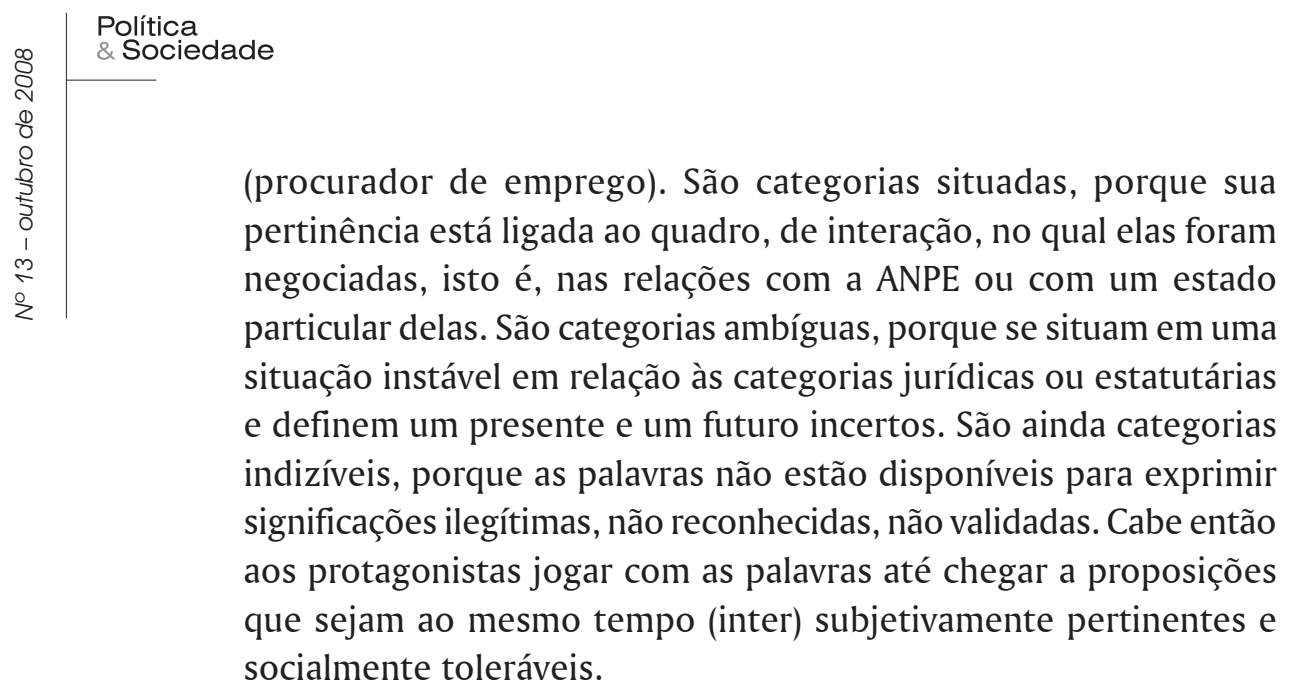

\subsection{Desempregado e não-desempregado: categorias mudas}

A apreensão, a compreensão e a análise de categorizações indígenas podem ser efetuadas recorrendo-se a métodos muito diversos, ainda que permitam a coleta de materiais linguíísticos. $\mathrm{O}$ exemplo precedente apóia-se na observação de interações assimétricas, completada pela realização de entrevistas com os protagonistas centrados em seu encontro, e o último exemplo recorre à observação de conversas comuns em grupos de tamanho reduzido, associada à condução de entrevistas junto a alguns participantes. Outro procedimento, particularmente utilizado, consiste em efetuar entrevistas aprofundadas e abertas, centradas nos percursos biográficos dos sujeitos. Este método experimentou um desenvolvimento inédito nas últimas décadas (BLANCHET \& GOTMAN, 1992), o que marca um interesse inegável de muitos sociólogos pelo relato das pessoas. Mas esse interesse não informa a respeito do lugar das categorias não oficiais na produção dos resultados, tanto que as posturas sociológicas face às entrevistas são contrastadas: segundo a concepção da categorização que o pesquisador endossa, o estatuto desse relato será muito diferente.

O que está em jogo é o estatuto acordado ao que as pessoas contam, mas também aquele que é dado às categorias oficiais e institucionais que servem para legitimar e administrar a ordem social. Levar a sério o relato das pessoas, isto é, considerar as ca- 
tegorizações indígenas como processos-chave de constituição do sentido no discurso, supõe colocar de lado as categorias oficiais para levar em conta a materialidade da linguagem. Isto implica em não se limitar à análise da nominação e dos usos de categorias codificadas: não é suficiente notar que certo sujeito se diz desempregado, enquanto que outro utiliza outras palavras para definir sua situação (procurador de emprego, artista, trabalhador ou qualquer outro vocábulo). Além das palavras e da dimensão léxica do discurso, os sujeitos fazem das frases, isto é, matizam, relativizam, argumentam, exprimem ambivalências etc. Percebe-se, assim, outra dimensão nos jogos de linguagem que não se reduzem apenas às variações de vocabulário. Certamente não é insignificante considerar-se desempregado mais que outra coisa, ser considerado como desempregado ou ver-se atribuir esta qualidade por outrem. Mas não se podem evitar certos mecanismos de categorização: cada palavra não tem uma significação unívoca e partilhada, o sentido é produzido pela combinação de categorias linguiísticas, que podem associar categorias exclusivas de um ponto de vista normativo (desempregado e não-desempregado, por exemplo). Os jogos de linguagem traduzemse por encadeamentos tanto previsíveis, porque evocam categorias oficiais e, nesse sentido, compreensíveis, ao menos na aparência; quanto imprevistos porque anulam os códigos habituais e são incoerentes, ao menos na aparência. Eles passam pelos agenciamentos estruturados, por argumentações que organizam as categorias. Gostaria de fazer alguns esclarecimentos sobre esses jogos, regulados, de linguagem apoiando-me num exemplo de análise de entrevistas biográficas realizadas com desempregados, mas não me deterei nos aspectos estritamente metodológicos da postura sociológica colocada em prática, porque ela já foi amplamente apresentada e discutida (DEMAZIÈRE \& DUBAR, 1996, 1997).

Este exemplo concerne a uma enquete realizada a partir de entrevistas em 1993 e 1994 junto de jovens que concluíram sua escolaridade em 1986, tendo no máximo um CAP $^{14}$, BEP ou

14 CAP: Certificat d' Aptitude Professionnelle. Certificado de Aptidão Profissional, é um diploma de nível médio. (N.T). 
um certificado dos colégios ${ }^{15}$. Cerca de cento e sessenta pessoas foram entrevistas. Uma amostra foi extraída, correspondendo aos percursos de inserção profissional mais marcados pela dificuldade de acesso ao emprego: 22 casos foram isolados a partir das informações coletadas com a ajuda de um questionário aplicado pouco antes da realização da entrevista. Eles partilham as seguintes características: no momento da enquete não têm emprego e declaram estar procurando um, e durante os sete primeiros anos de vida ativa conheceram longos períodos de desemprego (ao menos quatro anos de duração acumulada). As codificações estatísticas (emprego e estatutos de emprego, desemprego, formas de inatividade) foram utilizadas para retraçar os percursos que explicitam uma forte proximidade das situações objetivas, objetivadas.

Por construção, essas situações são particularmente desfavoráveis, pois concernem àqueles egressos do sistema educacional nas escalas mais baixas que se confrontaram com importantes obstáculos nas suas tentativas de inserção profissional, a ponto de terem sido beneficiados pelos dispositivos públicos, que se supõe oferecer "uma segunda chance", para retomar as expressões da administração. No registro estritamente jurídico, esses jovens são desempregados, procuradores de emprego. Mas, sem dúvida, essa categoria não é suficientemente precisa para explicar sua situação e seu percurso. No registro administrativo, outras categorias estão disponíveis funcionando como justificativa das políticas públicas de luta contra o desemprego: "jovens sem diploma", "jovens em dificuldades”, "jovens de baixo nível” (DEMAZIÈRE, 1993). Sem dúvida, essas categorias estão um pouco deslocadas, pois esses jovens não tiveram muito acesso a essas ajudas de inserção profissional. No registro mais difuso da opinião pública e das categorias coletivas veiculadas pela mídia principalmente, é a categoria exclusão que emerge e se difunde na mesma época. Sem dúvida, desse ponto de vista esses jovens podem ser qualificados de excluídos, na medida em que não são nem desempregados comuns, nem "baixo nível" comuns, mas estão numa situação que resiste às políticas clássicas. O leque das categorias oficiais que, no inicio de 1990, podiam ser

15 BEP: Brevet d'Étude Professionnelle. Brevê de Estudos Profissionais, também é um diploma de nível médio. (N.T). 
mobilizadas para identificar esses jovens, é muito amplo. Assim, será necessário traçar com precisão as inflexões, transformações e mutações sucessivas dos discursos oficiais sobre os jovens e sobre a sua inserção; o que não é feito, apesar dos primeiros esclarecimentos (GUYENNOT, 1998a, b).

Mas o que isso importa, pois certamente categorias oficiais não faltam, o que é compreensível se lembrarmos que a inserção profissional dos jovens, em particular os menos diplomados, constituía-se numa verdadeira causa nacional. Dito de outra maneira, os discursos que os jovens desenvolvem para dar conta de sua situação se desfiguram num plano anterior marcado pela proliferação de categorias oficiais. Estariam estas sendo utilizadas pelos jovens para contar suas experiências, para dar sentido ao seu percurso, para engajar um dialogo implícito com o outro e produzir um contradiscurso? A simples leitura das entrevistas mostra que o vocabulário de inserção profissional não é muito utilizado: os jovens não se dizem "em dificuldade", "excluídos" ou mesmo "desempregados". Eles não recorrem a essas expressões para descrever seu percurso e caracterizar sua situação. E seus relatos combinam os conjuntos mais diversos de categorias, que não podem facilmente ser resumidos por uma posição numa nomenclatura, numa codificação.

Se desempregado é uma categoria de referência, ela está, sem dúvida, muito ligada à instituição ANPE, que esses jovens não frequientam, pois são administrados por missões locais para os jovens, para ser utilizada como tal. Uma categoria como a exclusão parece não ter sentido subjetivo, porque funciona mais sobre a atribuição do que a reivindicação e é uma rotulação estigmatizante e desqualificante: esses jovens são chamados de excluídos, mas não se definem nesses termos. Assim, as categorias oficiais, pertencentes aos códigos jurídicos, aos discursos oficiais, às línguas dos especialistas, não aparecem facilmente nos discursos autobiográficos produzidos no desenrolar de uma conversa com um sociólogo. Elas não têm um efeito tão forte sobre os jogos de linguagem indígenas que se constituiriam em recursos adequados para ordenar o relato de sua trajetória e dar sentido ao seu percurso. Certamente elas encontram eco quando são explicitamente propostas aos sujeitos a fim de que classifiquem sua progressão, como ocorreu com o questionário submetido a esses 
jovens, mas não são suficientemente interiorizadas para organizar os relatos suscitados no decorrer de uma entrevista aberta.

Se os sujeitos, mesmo os que experimentam as piores dificuldades para se inserir na vida profissional e adulta e que têm baixos recursos escolares, não são receptores passivos das categorias oficiais, inversamente, eles não falam uma língua vernácula, mobilizando um vocabulário específico. Para explicitar o sentido de seu percurso, o sujeito utiliza efetivamente um código narrativo, optando por algumas maneiras de falar de sua situação em relação ao emprego, dentre muitas outras possíveis. Esse código, que é experimentado, afinado, retificado no decorrer da entrevista, à medida da produção do relato e das retomadas das sequiências da narração, se apóia num vocabulário privilegiando certas palavras. Mas não são as palavras como tal que contam, porque elas estão inseridas num raciocínio, estão associadas a julgamentos de possibilidades, são afetadas por valores. As categorias do código narrativo não são puramente descritivas, e colocá-las em prática é criar uma confusão que não decorre somente de uma "semântica" da ação, mas também de um "pragmatismo da palavra” (RICOEUR, 1984, p. 119). Essa é uma característica essencial da condução do relato: a evocação do passado implica o julgamento do presente que suscita a antecipação dos futuros possíveis. A narração é sempre interpretação e tomada de posição, ela é "um processo criador de valores" (GREIMAS, 1970, p. 74).

Bem entendido, o código narrativo de um discurso pode ser descrito a partir do inventário das palavras pronunciadas, e a dimensão léxica oferece uma primeira pista para identificar e diferenciar os códigos narrativos. Por exemplo, no corpus de entrevistas de jovens, as palavras utilizadas para falar do trabalho (em seu sentido genérico mais amplo e fluído possível) eram extremamente diversas: "dar uma mãozinha, pequenos bicos, um trabalho fixo, um engajamento, uma vaga, um verdadeiro emprego, um plano infernal, meu pequeno negócio, pequenas tarefas, substituições, um contrato definitivo, um trabalho seguro, um verdadeiro trabalho, um SIVP ${ }^{16}$, exploração, um trabalho que me apaixona, meu ofício, meu ramo, uma profissão,

16 SIVP: Stage d' Initiation à la Vie Professionnelle. Estágio de Iniciação à Vida Profissional. (N.T). 
alguma coisa para ganhar dinheiro, pequenos trabalhos, um TUC ${ }^{17}$, pequenas experiências, um trabalho de temporada, um posto onde você fixa-se, um ofício que me agrada, um verdadeiro ofício, qualquer coisa estável, um trabalho comum...”. Os termos empregados remetem a universos de referência e a sistemas de valores plurais, a dimensões variadas do trabalho (o estatuto, a estabilidade, o ofício, as condições de trabalho, as potencialidades de futuro etc). A identificação de certas situações profissionais, como "um verdadeiro emprego", "o verdadeiro trabalho", "um verdadeiro ofício", mostra que as palavras estão inseridas nos raciocínios que classificam as situações, que argumentam pontos de vista, que justificam categorizações. É, portanto, a ordenação das categorias que deve ser analisada e reconstituída, de maneira a compreender os argumentos e justificações que dão sentido ao percurso profissional.

Analisando as 22 entrevistas de jovens com trajetos de inserção profissional os mais opostos, tentei identificar a organização das categorias colocadas em prática por cada um para contar seu percurso, dar sentido à sua situação e, finalmente, prestar conta da sua própria identificação categorial. Cada entrevista foi esquematizada seguindo as etapas de um procedimento explicitado segundo outro ponto de vista (DEMAZIÈRE \& DUBAR, 1997, cap. 7): levantamento de categorias linguí́sticas utilizadas para contar as etapas e eventos subjetivamente importantes, explicitação das relações de conjunção e de disjunção entre essas categorias, identificação das tomadas de posição e de valorizações diferenciais, clarificação de diversas teses desenvolvidas sobre o que aconteceu, reconstituição da argumentação que articula essas sucessivas situações, descoberta do enredo que organiza o relato.

Os relatos dos oito primeiros anos de vida ativa mencionam muitos eventos e episódios, que são narrados como fracassos: tentativas, em vão, de obter um emprego, seguidas de estágios de formação sem continuidade, frequiência às instituições sem benefício, experiências em trabalhos desinteressantes, rupturas brutais de contratos de trabalho etc. O percurso é narrado como uma sucessão de episódios descontínuos, sistematicamente abortados. As

17 TUC: Travail d' Utilité Collective. Trabalho de Utilidade Coletiva. (N.T). 
relações com os outros são restabelecidas a partir de dificuldades que surgem constantemente, qualquer que seja o quadro relacional referente: conflito com superiores hierárquicos, bloqueio das situações com os conselheiros de inserção profissional, traição por intermediários que fizeram promessas, incompreensão na família, ruptura com pessoas de confiança etc. As relações são narradas como a repetição de fracassos e a acumulação de desilusões em relação a outrem. Se os percursos estão marcados pela repetição dos mesmos impasses, eles são relatados como uma degradação lenta, mas irresistível, que conduz progressivamente ao isolamento, ao banimento, ao desencorajamento, ao fechamento de toda perspectiva. Os episódios depressivos são freqüientemente mencionados, mesmo que com palavras muito diversas.

Todas essas experiências relatadas - profissionais ou extraprofissionais, relacionais ou afetivas, pessoais ou íntimas - são organizadas para alimentar um ponto de vista, subjetivo, sobre o que se passou. Esta tese poderia ser resumida assim: esses jovens acumularam fracassos, nunca encontraram nada de sério, não sabem mais o que fazer, não tem nada (ou ninguém) com o que (ou quem) contar, eles não conseguem sair, estão presos num círculo vicioso que os faz deslizar de fracassos a impasses. Em síntese, eles conheceram somente experiências sem continuidade e sem futuro, que se tornaram sem sentido nem significação. Isso coloca um problema específico de nominação, pois o que não tem sentido, ou o perdeu, também não tem nome. Como testemunham a frequiência de marcadores da negação ou da restrição (não, mais, sem, que...) nas entrevistas. Os jovens não utilizam o termo desemprego e vêem-se ainda menos como desempregados; mas outro termo é utilizado de maneira recorrente, é "galére"18 nas formas substantivada ou verbal. Esse é um termo que não tem sentido preciso e é utilizado para evocar amplos períodos ou reunir eventos ou episódios aparentemente diferentes. Assim, sua função é de dizer o indizível, de enunciar uma palavra sobre coisas que são dificilmente exprimíveis. Por isso é preferível retomar esse termo em vez de privilegiar uma

18 A "galère" é, nesse caso, uma "vidinha", vida medíocre, cheia de tédio, dificuldades e provações (N.R.). 
outra categoria, deslocada em relação ao linguajar dos jovens, para nomear um tipo de relato: os relatos de "bico".

Em sua forma típica esses relatos são dominados pela "vidinha", onde parecem se esgotar e se fechar. Entretanto, certas passagens fazem emergir, muitas vezes de maneira brusca e sem articulação com as experiências passadas, fortes aspirações de saída dessa "vidinha" e de acesso a uma posição profissional que preserve dessa vida. Os relatos oscilam, sempre de maneira breve e provisória, para um outro lugar, que é também um sonho mais ou menos inacessível que se ousa apenas vislumbrar. Essa posição projetada corresponde ao que os jovens consideram como normal ou justo para si mesmos, àquilo que estimam ter direito e que precisamente não obtiveram porque vivem penosamente, sem meta. É também o que eles jamais viveram, e que alguns denominam como um “verdadeiro emprego". É portanto o emprego que está aqui em questão, mas não qualquer um, não o emprego que se pareceria com os que os jovens já conheceram, que não levaram a nada, e que aparecem implicitamente como "falsos" empregos. Na análise, os relatos aparecem então estruturados pela disjunção entre a "vidinha" e o "verdadeiro emprego", mas esta tensão parece primeiramente irredutível, quando ela é condensada em uma frase do gênero: "Até agora, eu vivo mal; quero um verdadeiro emprego".

Há, entretanto, um enredo que une este par disjuntivo. Ele diz respeito à posição do narrador (o jovem que conta fragmentos de sua história ao ser convidado por um pesquisador) em relação a esta oposição: reporta-se mais precisamente às modalidades de passagem da "vidinha" ao "verdadeiro emprego" e, portanto à oscilação do relato e à inversão da trajetória narrada. Entre "vidinha" e "verdadeiro emprego", qual é a posição dos jovens e qual posição eles se atribuem? Entre um passado dominante/invasor e dominado/ invadido pelo "vidinha" e um futuro incerto e inconsistente, como os jovens definem sua situação? O desemprego, ao mesmo tempo privação de um emprego e antecipação de um emprego, pode justificar esse estado? Mais uma vez, o desemprego não é uma categoria pertinente, e o que os jovens dizem não é que eles não estão trabalhando, mas que não sabem, que estão na incerteza, que aguardam. O que é essa espera? 
A espera significa, propriamente falando, que esses jovens desejam alguma coisa que não obtiveram e que, todavia, situam como algo que é socialmente esperado: eles não têm o sentimento de estarem inseridos, no emprego e na vida profissional, assim como na vida adulta. Aqui não há,definição precisa da inserção, mas a impressão de não ter conseguido se sair bem, embora tenha chegado a um momento da existência no qual é normal sair do “tempo"insuportável e, portanto, provisório da "vidinha". Por isso as evocações da espera são às vezes feitas em um tom dramático, acompanhado de verdadeira angústia. É por isso que elas constituem uma face dos relatos preparando um desfecho e participando do enredo. A espera, e não o impasse, é a tensão em direção a alguma coisa ou a alguém. De fato, a face escondida da espera é uma perspectiva, à qual vale mais se ligar para não soçobrar. É também uma inversão narrativa, definindo um imaginário em ruptura radical com o episódio descrito anteriormente. É o surgimento de um futuro que inverte brutalmente a situação vivida. Trata-se de um futuro providencial, de uma perspectiva utópica, sem lugar nem temporalidade, caída do céu, que se funda no contraste em relação aos infortúnios anteriores. Sua legitimidade parece residir nessa brusca inversão. O relato oscila entre dois termos opostos, como se quanto mais houvesse fracasso, mais haveria sucesso.

Essa inversão de perspectiva é argumentada pela ajuda providencial de um personagem, que realiza a mudança como por um passe de mágica. Na verdade, a espera é tanto mais consistente, reivindicada como portadora de futuro, prenunciadora de futuro, que esses jovens podem sustentar seus relatos em um (ou vários) personagem (ns) investido (s) de um poder, e com o qual eles mantêm uma relação de promessa/confiança. As possibilidades de passagem para o "verdadeiro emprego" estão suspensas na promessa do que se pode chamar de um 'Outrem' poderoso, em quem eles têm confiança. Esse personagem jamais é um empregador que poderia dar direta e imediatamente um emprego ao narrador. Se ele o pudesse, porque então ainda não o teria feito? Mas é alguém que controla o acesso às etapas de passagem para o "verdadeiro emprego": concursos administrativos, diplomação, exames profissionais etc. É alguém que possui as informações sobre um universo totalmente 
estranho aos jovens, ou seja, que detém as chaves de acesso a um "verdadeiro emprego". Assim, aos impasses e às fraquezas das redes características da "vidinha", os jovens opõem normas formais e procedimentos explícitos (concurso, exame, diploma...), que regulamentam a obtenção de um "verdadeiro emprego", e são, portanto, intervenções mágicas capazes de inverter a ordem das coisas. São mecanismos burocráticos que garantem um acesso automático a um "verdadeiro emprego" e protegem definitivamente da "vidinha", da qual os jovens procuram inutilmente escapar.

O acesso ao "verdadeiro emprego" é definido por várias crenças: um princípio burocrático permite acessá-lo quando se corresponde a critérios fixados de maneira impessoal; o princípio da reviravolta permite a abertura de oportunidades a partir de uma situação, aparentemente sem saída; o princípio de justiça, oposto à indicação ou ao pistolão, regula o acesso ao "verdadeiro emprego" de maneira que a inferioridade pode se tornar um trunfo. Mas esse universo de crenças só merece crédito se os personagens, sejam eles amigos, conhecidos ou interventores institucionais (formadores, orientadores...), produzem atos que são percebidos como engajamentos ou proferem palavras que são interpretadas como promessas. Melhor, esses personagens poderosos aparecem como oficiantes que fazem justiça, que dão um lugar aos mais necessitados, que oferecem uma chance aos mais ameaçados. Suas intervenções têm uma função de sustentação e de atualização das situações imaginárias desses jovens. Contrabalançam outros episódios de seu relato, os pelos quais eles exprimem que eles não têm mais nada, nenhuma perspectiva de ação, nenhuma pista a explorar e talvez mais nada a perder. Eles confiam assim em intermediários, esperando poder se beneficiar de reparações que os retirarão definitivamente da "vidinha" e farão oscilar a situação de espera na direção do "verdadeiro emprego", afastando pela mesma ocasião a ameaça de cair na classe dos assistidos, os que recebem o Rendimento Mínimo de Inserção.

Trata-se também, e, sobretudo, de um mundo da ajuda, pública ou privada, da assistência providencial, mas pelo trabalho, outorgado pelo Estado Providência ou pela intervenção de um conhecido. Sob o plano da argumentação, esse mundo corresponde a 
entrevistas que exprimem a "vidinha", as decepções, a revolta ou o desânimo, e desembocam numa "reviravolta" na qual alguns jovens não parecem acreditar verdadeiramente ao revelar sua "espera" de uma inversão de sua situação. Esses "milagres" não são justificados nem pelo passado relatado no modo da repetição e da ausência ("não aconteceu grande coisa"), nem pelo presente explicitado em palavras de angústia ("tenho medo"), de incertezas ("não sei”) e de vazio ("não tenho nada"). Eles surgem da evocação de um atuante providencial sobre o qual o jovem não diz grande coisa a não ser que ele seguramente intervirá, que não poderá abandoná-lo sem mais nem menos, não poderá deixá-lo. $O$ silêncio, as frases interrompidas e inacabadas, as dificuldades de elocução assim como o emprego frequiente da forma passiva testemunham dificuldades de defender uma alternativa positiva.

Como justificar essas categorizações não-oficiais de uma situação- e de um percurso- que o ponto de vista oficial qualificaria como exclusão e que não são nomeadas explicitamente como tal? 0 desemprego também não consegue, porque os relatos biográficos são enredos, isto é, combinam certos episódios e eventos, selecionados e tidos como subjetivamente significativos, ordenam-nos em uma temporalidade biográfica que articula passado, presente e futuro, e que é irredutível à qualificação de uma situação diacrônica, e contam uma história que argumenta a construção de uma significação. No exemplo desenvolvido aqui, esta argumentação pode ser designada pela expressão "relatos de salvação", para sublinhar o papel central atribuído a um personagem providencial num mundo opaco e injusto. Esse mundo é caracterizado ao mesmo tempo por relações de proteção (um Outrem poderoso faz o papel de protetor podendo fornecer um "verdadeiro emprego") e por situações protegidas (esse "verdadeiro emprego" vale como garantia para escapar definitivamente do pior, isto é, de "uma vidinha para sempre"). Por isso propus chamá-lo de "mundo do trabalho protegido".

Porque, mesmo que a explicitação de situações vividas pelos jovens seja efetiva - o que chegou mesmo a ser solicitado e acompanhado por meio de uma entrevista aprofundada - isso não conduz a uma nominação traduzida no léxico ou nas apelações. As categorias oficiais não aparecem como recursos narrativos, balizas 
permitindo ancorar os relatos, ou levantamentos sólidos para a definição de situação. O que dizem os jovens sobre si mesmos? Apesar da "vidinha", eles querem um emprego e exprimem esta reivindicação com força em forma de reclamação. Se eles não produzem categorias explícitas, é sem dúvida porque sua antecipação do futuro e a enredo de seu percurso (a intervenção de um outrem poderoso que os salve) estão muito distantes em relação às exigências instituídas, fortemente estruturadas em torno da retórica do projeto profissional, e substituídas por mediadores do emprego ou membros de seu entorno. Como nomear um ponto de vista que é heterodoxo ou ilegítimo, sujeito à desqualificação em nome de um realismo necessário? Seu ponto de vista sofre de uma deficiência de legitimidade social e confronta-se com quadros cognitivos que ficam na sombra do relato mas estão fortemente estabelecidos. Os jovens entrevistados produzem categorizações mudas porque querem um emprego, mas sem respeitar as regras da procura de emprego; porque, de certa maneira, eles são desempregados mesmo não o estando, isto é, sem ser desempregados comuns; porque eles se distanciam das categorias oficiais. Para fazer eco a este ponto, proponho um terceiro exemplo, caracterizado por condições sociais de enunciação claramente diferenciadas.

\subsection{Desempregado e não-desempregado: categorias entrecruzadas}

Os coletivos organizados de desempregados oferecem outro campo para a análise dos processos de categorização social, na medida em que a participação em uma ação coletiva reivindicativa, por conseguinte, estende-se a certa duração, não é uma atividade legítima para um desempregado. Nenhum termo está disponível para nomear esse fenômeno: qual seria a significação da expressão "militante-desempregado", estaria calcada sobre o bem conhecido "militante-operário"? Forçosamente admite-se que esta expressão não é de uso corrente e não tem sentido claro, pois é empregada a torto e a direito. É que os desempregados são categorizados, sob o registro jurídico como procuradores de emprego: ser desempregado não é somente estar privado de emprego, é estar engajado 
em uma busca de emprego e poder-dever justificá-la. Da intensidade da procura de emprego depende a legitimidade da pretensão a um emprego e, além disso, a qualidade do desempregado. Por outro lado, o contencioso só admite o exercício de uma atividade benévola não-lucrativa se ela não onerar o tempo de procura de emprego (WILLMANN, 1998, p. 448). A atividade reivindicativa dos trabalhadores não é somente contraditória com as obrigações do estatuto, salvo se for episódica e irregular, mas é ainda ilegítima, pois o sentido do desemprego deve estar enquadrado pela mobilização pessoal na conquista de um emprego. Assim, o não-nomeado é também um não-nomeável.

Entretanto, algumas formas de ação coletiva de desempregados são encorajadas, legitimadas, nomeadas: são os grupos orientados à busca de emprego e fundados numa troca de experiências, no conhecimento e nas redes de cada um na prospecção do mercado de trabalho. O trabalho de preparação do currículo dos membros ou de redação das cartas de motivação, as simulações de entrevistas de emprego, as visitas a empresas com apresentação dos currículos de todos os membros, a organização de prospeç̧ões telefônicas, a constituição de uma rede de antigos funcionando como uma caderneta de endereços, por exemplo, são atividades habituais desses grupos (DEMAZIÈRE, 1998). Esses coletivos de busca de emprego se apóiam na figura, oficial e legal, do procurador de emprego. Eles estimulam a procura de emprego, constitutiva da codificação do desemprego e reagrupam desempregados que acreditam na possibilidade de arranjarem um emprego. O sentido dessas iniciativas é, a partir da troca de experiências, das competências dos membros, aumentarem as chances, para cada um, de sair dessa situação, de escapar da condição de desempregado. Essas atividades parecem suficientemente próximas dos serviços rotulados, privados ou públicos, mercantis ou não, prestados aos desempregados: círculos de busca de emprego da ANPE, sessões de procura de emprego financiadas pelos poderes públicos...

As relações com a categoria desempregado podem ser esclarecidas pela análise das nomeações, não-oficiais, que esses grupos se dão, e mais ainda pelas que seus adeptos reivindicam para si. Procurar-se-ia inutilmente os termos desemprego ou desempregados 
nos nomes que esses grupos escolheram. São, sobretudo, termos como emprego ou empresa que ocupam um lugar de destaque, indicando quais são os objetivos e o alvo procurados: "Quadros Parceiros das Empresas”, "jovens diplomados” (Syner 'JD) ${ }^{19}$, "Conjunto Para o Emprego", "Quadros de Experts Associados", "Diplomados Para o Serviço das Empresas", "Agrupamento de Pesquisa de Emprego e de Serviços”. Os próprios membros e participantes não se designam desempregados, ao menos essa palavra não aparece nos propósitos recolhidos durante as entrevistas biográficas (DEMAZIÈRE, 2000 b). Alguns explicam que o termo é "pejorativo" e a maior parte rejeita igualmente a nomeação "demandador de emprego" correspondente à categoria jurídica, justificando que ela evoca um engajamento insuficiente na busca de emprego: "Eu não peço nada, tem-se a impressão de estar numa situação de fracasso, e esse não é um bom começo se quer conseguir um emprego". Os termos mais frequientemente empregados são os de "procura de emprego" e de "demandador de emprego", o primeiro amplamente consagrado pelo uso, e o segundo menos difundido, mas justificado pelo fato de que sua significação remete a qualidades apreciadas pelos empregadores, tais como o "dinamismo", a "motivação", a "determinação", a "responsabilidade", o "desejo": "Aquele que procura engaja-se resolutamente e mostra seu dinamismo", "Você vê, isso quer dizer que eu não estou pedindo um emprego. É esse o truque, sentir-se responsável pelas suas buscas". Certos desempregados definemse como "prestadores de serviço", para inverter a dessimetria da relação na qual se engajam com os recrutadores como candidatos: "É necessário primeiramente se convencer de que se pode oferecer alguma coisa à empresa, e em seguida persuadir-se de que o patrão precisa de você. É necessário contornar as coisas; isto é, eu sou prestador de serviço e as empresas procuram candidatos. Dizer desta maneira parece tolo, mas isso muda tudo na cabeça”.

$\mathrm{O}$ abandono do termo desempregado e o fato de recorrer a alternativas produzem um sentido que parece muito próximo da categoria desempregado, mais exatamente do modelo normativo que a sustenta. Deslocar o modelo do desempregado para outra

19 Jovens diplomados (Syner' JD): é o nome de um sindicato. (N.T.) 
categoria (procurador de emprego ou prestador de serviços) é indicar que a categoria oficial de desempregado foi esvaziada em seu sentido, ou mudou de sentido. A mudança de vocabulário é uma marca discursiva paradoxal, pois ela significa a adesão ao sentido instituído, definido pela disponibilidade e pela procura ativa de emprego; rejeitar a denominação desempregado, significa definir-se como um "verdadeiro desempregado". Por assim dizer porque, para as pessoas interessadas, essa expressão perdeu toda significação na medida em que o termo desempregado se reaproxima de uma significação inversa como a de "falso desempregado": ser desempregado é não ser ativo na procura de um emprego, é não se mostrar suficientemente motivado, é deixar-se levar.

Esses jogos ilustram as relações de interdependência entre as categorias oficiais e não-oficiais (ou indígenas): as segundas remetem a um sentido anterior as primeiras, a um estado considerado como resolvido; a nova categorização tem somente o objetivo de reencontrar uma significação estável, mas obscura, de mesclar um sentido estabelecido mas diluído. A categorização indígena não é somente, como no primeiro exemplo estudado, uma resposta à crise das categorias institucionais, por não consistir apenas em misturar os arranjos locais em torno de categorias provisórias e operatórias. Trata-se desta vez de ponderar sobre situações incertas para fixar significações, de re-categorizar para substituir as categorias oficiais enfraquecidas. Por outro lado, as categorizações propostas pelos desempregados engajados nos grupos de auto-ajuda para a procura de emprego têm alguns traços familiares com as categorias oficiais. Primeiramente, elas são reivindicadas por pessoas, mas são também discursos de instituição, como testemunham as referências frequientes a um terceiro, expressas durante as entrevistas sob a forma de imperativos como "é necessário". Certamente os agrupamentos de desempregados não são organismos oficiais ou autoridades estabelecidas, mas eles também forjam categorias coletivas que sustentam seus objetivos e propostas a seus adeptos. Isso sem dúvida porque elas têm pouca legitimidade fora desse círculo não chegando a impor suas categorizações. Por outro lado, elas são às vezes derivadas, se não retomadas, das categorias oficiais: procurador de emprego decorre da norma imperativa de busca de emprego, exprimindo-a 
de maneira mais literal do que a expressão jurídica demandador de emprego. Finalmente, esses jogos de linguagem chegam a criar um vocabulário não-oficial e pouco reconhecido fora dos círculos onde foi forjado, mesmo visando um retorno ao sentido original, isto é, historicamente estabelecido, mas vivido como verdadeiro, do desemprego. Em outras situações, e no centro de outros coletivos de desempregados, as categorizações comuns das situações se opõem deliberadamente a toda significação alógena.

Quando as ações coletivas organizadas não são orientadas principalmente para a procura de emprego, os que participam não têm as mesmas reticências em relação à categoria desempregado, ao contrário. O discurso legitimando a ação é articulado em torno da figura coletiva do "desempregado", as ações reivindicativas são conduzidas em nome dos "desempregados", as trocas entre pares utilizam abundantemente esse termo, as situações individuais são caracterizadas da mesma maneira. Eu me deterei neste último aspecto, que remete às maneiras pelas quais os sujeitos se autocategorizam nas trocas com o sociólogo, mas também nas conversas com os outros participantes do grupo. Eu me apoio numa pesquisa conduzida com cerca de trinta coletivos e associações de desempregados participantes de atividades reivindicativas: manifestações de rua, ocupações de locais públicos, distribuições de panfletos, interpelações das autoridades (DEMAZIÈRE, 2002 a).

As enquetes realizadas junto de adeptos que haviam participado regularmente das atividades desses coletivos mostram uma grande variedade de situações individuais, apreendidas pelas categorias de estatutos: demandadores de emprego registrados na ANPE, estudantes inscritos na universidade, aposentados percebendo uma pensão, assalariados titulares de um emprego, intermitentes reconhecidos pela Caisse des congés-spectacle ${ }^{20}$, estagiários em formação, ativos ocupados em tempo parcial, militantes desligados de seus sindicatos, beneficiários do RMI, jovens não escolarizados inscritos numa missão local, inativos não percebendo nenhum rendimento

20 Caisse des congés-spectacle: repartição pública que distribui auxílio, em dinheiro, destinada aos artistas, entre um período de apresentação de espetáculo e outro, normalmente durante a preparação do próximo trabalho. N.T. 
pessoal etc. A observação de numerosas trocas, reuniões e discussões, mostra que essas codificações estatutárias não são retidas pelos participantes como informações pertinentes para serem apresentadas e tipificá-los. Isso se concebe uma vez que o grupo, à imagem de todo o grupo de interesse, deve fabricar sua unidade anulando as diferenças entre seus membros. O outro é considerado um semelhante, apesar das diferenças estatutárias. Entretanto estas não se dissolvem em uma improvável categoria "guarda-chuva", lembrando sem dúvida que nem tudo é possível nos jogos de linguagem.

Uma dualidade se explicita com uma força variável segundo os coletivos e a intensidade da heterogeneidade estatutária de seus membros entre os "desempregados" e "aqueles que trabalham", que "têm um emprego". Estes não são verdadeiramente nomeados como categoria e são, sobretudo, diferenciados naquilo que não os caracteriza como desempregados: eles são o que se pode chamar de "não-empregados". Essa categoria por carência é, entretanto, claramente estabelecida e a distinção é amplamente partilhada quando se trata de descrever o grupo, sua composição, sua organização. Por outro lado, se esta diferenciação também parece presente e admitida, pode ser porque ela faça eco à denominação de certas federações nacionais de coletivos de desempregados (Movimento Nacional dos Desempregados e Precários, Ativos e Desempregados Ativos AC); isto é, as categorias públicas e fixas senão oficiais (DEMAZIÈRE \& PIGNONI, 1998).

Entretanto, os usos desta bipartição, levantados a partir das maneiras pelas quais as pessoas definem sua posição nessa classificação e qualificam aquela de um ou outro de seus pares, vêm perturbar as classificações esperadas: não se declaram e não são considerados como desempregados todos os que não têm emprego. As diferenças, como se poderá ver, não são consequiência do alargamento das fronteiras entre desemprego e emprego, mas resultam da construção de outros princípios de categorização. Esses últimos não são explicitados, porque provêm de lógicas práticas, mas a análise permite-lhes reconstituir, ou ao menos propor, uma interpretação a partir da repetição de observações empíricas: por que Christian se declara desempregado, enquanto sua atividade profissional faz-lhe faltar muitas reuniões e "encontros militantes"? 
Por que Josèphe se diz assalariada, enquanto trabalha em tempo parcial e conta com uma disponibilidade bem maior para o grupo? Por que Germain, que não tem atividade profissional e não deixa jamais Henri, seu alter-ego, qualificá-lo como desempregado sem se autodefinir como tal? As enquetes de campo não foram escassas em enigmas, elucidados progressivamente com a ajuda dos interessados, para os quais os esclarecimentos foram solicitados na medida em que se tornou necessário.

Tornou-se visível que todos os empregos não eram equivalentes. Isso vale igualmente para as categorias oficiais, mas as categorizações não-oficiais, apreendidas num contexto de enunciação preciso, introduzem outros princípios de distinção. Existe emprego que equivale a não-desemprego e emprego que equivale a desemprego, existem ativos ocupados que são desempregados e outros que não o são. $O$ estatuto não é insignificante ao se comparar Josèphe, funcionário da Educação Nacional e categorizado como não-desempregado, e Christian, intermitente do espetáculo em (sub) emprego e desemprego. Mas o que caracteriza os que têm um emprego e que são definidos e definem-se como desempregados, não é ter uma situação profissional instável e farta de risco de desemprego, é ter conhecido o desemprego no passado, seja de maneira repetitiva, seja mais pontualmente num período recente. Dito de outra maneira, é o fato de ter vivido pessoalmente a experiência do desemprego que os autoriza a se considerar desempregado e a ser legitimamente considerado como tal. Nesse contexto, o desemprego não é mais um marca desvalorizadora, é uma distinção. É um atributo que se torna inalienável como o são os títulos mais prestigiosos.

Simetricamente, nem todas as situações de não-emprego não se equivalem. Sabe-se que, se a definição jurídica do estatuto do desempregado (demandador de emprego) delimita uma posição suficientemente homogênea, isso não ocorre com a de inatividade, que reúne uma constelação de estatutos heterogêneos (escolarizado, estudante, em estágio de formação, aposentado e todas as formas de cessação antecipada de atividade, do lar....). A codificação institucional não traça fronteiras da mesma espessura entre o desemprego e cada um desses estatutos de inatividade, sendo alguns considerados 
muito próximos e outros muito distantes. As categorizações observadas em situação parecem igualmente levar em conta os estatutos, porque o que diferencia Germain e Henri, é que o primeiro está a partir desse momento aposentado, enquanto que o segundo está inscrito na ANPE e recebe uma ajuda de solidariedade específica. Os que não têm emprego e não estão desempregados são, em quase sua totalidade, aposentados ou pré-aposentados, que perdem sua qualidade de desempregado quando completam sua vida ativa. Todas as outras pessoas que não têm emprego classificam-se e são classificadas na categoria dos desempregados, independentemente de seu estatuto. Os aposentados diferenciam-se em dois aspectos: eles não estão mais expostos ao risco de privação de emprego e de fracasso na empresa de acesso ao emprego e - isso sem dúvida é o mais decisivo do ponto de vista dos participantes nas ações coletivas - podem participar dos grupos sem expor-se ao controle institucional da procura de emprego, nem sacrificar seu próprio percurso na ação coletiva, pois sua sorte está regularizada.

Nesse contexto, a categorização de algumas situações como de desemprego é bem perpendicular às categorias oficiais: ela reagrupa os que não têm emprego excluindo os que estão definitivamente protegidos do risco de desemprego, e os que têm um emprego, mas conheceram o desemprego. Esses princípios de classificação foram recompostos a partir de observações esparsas, mas numerosas, e eu poderia indicar alguns casos que não parecem entrar muito nesse esquema, às vezes, por deficiência de coleta de informação. Mas eles ao menos sugerem que, no contexto singular dos grupos de desempregados organizados e reivindicativos, o desemprego é redefinido e as situações individuais reinterpretadas em função da nova categorização. Nesse quadro o desemprego não é mais uma questão de privação de emprego, de disponibilidade, de procura de emprego, ou mesmo de empregabilidade, tantos traços distintivos e classificadores no universo codificado das instituições; ele é definido pela interpretação dos destinos pessoais e ganha, então, uma acepção mais ampla, ainda que socialmente arranjada. A análise poderia ser prolongada, mostrando notadamente que esta categoria extensa e fluída não é homogênea e unificada, mas que alguns desempregados parecem mais desempregados que outros. Mas 
o objetivo aqui não era descrever as graduações que caracterizam as categorias sociais, esta perspectiva já foi amplamente traçada. Era de mostrar que as categorizações são ao mesmo tempo móveis e consistentes, plásticas e coerentes, mutáveis e estáveis, em duas palavras: anárquicas e regulamentadas.

Através de três estudos empíricos, apresentei um quarto conjunto de abordagens da experiência do desemprego, que privilegia o estudo dos usos das categorias não oficiais, supostas a escapar do quadro fixado pelas categorias oficiais que situam o desemprego na tensão entre procura de emprego e exclusão. Foi desenvolvido no curso dos anos de 1990, quando os programas institucionais conseguiam cada vez menos controlar as atividades dos que se confrontaram com o desemprego e dando sentido a essa condição. O desemprego continua, entretanto, fortemente institucionalizado e permanece uma categoria de referência, no mínimo porque ele significa a antecipação de um emprego, ou principalmente, o direito a uma atividade profissional. Mas esse reconhecimento não conduz os sujeitos à identidade do desemprego; ao contrário, eles não se identificam completamente com a categoria oficial, se dizem desempregados, ainda que tomem distância desta designação. Eles fazem usos não previstos dessa categoria, usos mais ou menos reconhecidos por outrem, usos mais ou menos legítimos. O desemprego se torna então uma categoria polissêmica, investida de significações móveis e mais ou menos fluídas.

\section{Conclusão: o que é o desempregado?}

O que é o desemprego? Um drama destruidor das identidades pessoais e que ameaça a coesão da coletividade? Uma mobilização na procura de emprego realizada mais ou menos completamente? Uma provação revisada pelas reinterpretações mais ou menos coercitivas? Uma definição de situação susceptível de receber significações muito diversas? Essas formulações resumem as respostas que os sociólogos fornecem a essa questão. Elas podem se referir a conjunturas sócio-históricas particulares, pois apareceram sucessivamente no curso do tempo: nos anos 1930 a primeira, nos anos 1960 a segunda, nos anos 1980 a terceira, nos anos 1990 a 
quarta. Mas elas não foram sucedidas e substituídas umas pelas outras, em um movimento que teria instalado a mais recente numa posição hegemônica, porque elas não são traduções diretas das transformações da realidade do desemprego, que, se modificando, faria evoluir as análises dos sociólogos. Elas exprimem, sobretudo, estados diferentes das tensões entre as lógicas de categorização, estados que resultam, em parte, da história das sociedades e, em parte, das posturas teóricas dos pesquisadores.

Essas quatro posturas correspondem a muitas maneiras de vislumbrar as articulações entre categorias oficiais e categorias não oficiais e, por consequiência, construir um ponto de vista analítico sobre a categorização dos desempregados. Neste primeiro caso, a análise sociológica está centrada na interiorização dos esquemas institucionais pelos indivíduos, de maneira que as categorias nãooficiais são valorizadas, situando-se na dependência das categorias oficiais. Os desempregados aparecem então como um grupo à parte, e a experiência do desemprego é determinada por uma condição objetivante, homogênea e uniforme.

No segundo caso, a análise sociológica está centrada na medida da eficácia das normas que definem o estatuto de desempregado, de sorte que as categorias oficiais anulam as categorias não-oficiais. Os desempregados são definidos como agentes estratégicos em busca de emprego e a experiência do desemprego é levada a uma distância em relação ao emprego e ordenada segundo o volume de procura de emprego.

No terceiro caso, a análise sociológica está centrada na compreensão das significações vividas e das (re-) interpretações subjetivas de uma condição cujo sentido é programado, de maneira que as categorias oficiais enquadram as categorias não oficiais. Os desempregados são considerados como sujeitos e a experiência do desemprego é apropriada de diversas maneiras segundo os recursos pessoais.

No quarto caso, a análise sociológica está centrada na descrição das atividades sociais e linguiísticas que contribuem para reconstruir o sentido em situação, de maneira que as categorias não-oficiais afastam-se das categorias oficiais. Os desemprega- 
dos são considerados como pessoas engajadas nas interações e a experiência do desemprego é transformada e trabalhada em jogos de linguagem variados.

O que diferencia essas abordagens não é somente, nem mesmo principalmente, o fato de que elas dão uma coloração diferente à experiência do desemprego. É, sobretudo, o que elas enunciam sobre o que são os desempregados; não o conteúdo da categoria, mas os princípios que presidem sua formação, os processos de atribuição dessa qualidade moral. Para as duas primeiras, uma realidade homogênea e uniforme impõe-se aos indivíduos, que são transformados em desempregados pelo jogo de eventos cujo sentido impõe-se pela significação dominante que se faz autoridade. Num caso, este sentido remete ao modelo desvalorizador da exclusão do estatuto de referência, que é aquele do trabalhador ocupado, e num outro ao modelo valorizado do procurador de emprego antecipando a obtenção de uma atividade profissional. Para os dois seguintes, o desemprego é investido de significações plurais e múltiplas, que se constroem entre um sentido atribuído pelas instituições e as interpretações dos sujeitos, pela negociação sobre a legitimidade das definições da situação. Num caso, os desempregados permanecem marcados pela rotulação institucional e tentam afastar-se reformando seu mundo pessoal vivido e, noutro, os desempregados distanciam-se das categorias oficiais, mas jogam com elas, reorganizam-nas, subvertem-nas, transformam-nas em categorias contínuas. Igualmente, a primeira distinção é atravessada por outra, que diferencia uma visão sociológica, orientada para a total eficácia das significações herdadas e oficiais, e uma visão sociológica centrada na análise das condições de emergência de significações não-oficiais, oficiosas.

O que é um desempregado? Não há uma resposta única, não por razões factuais, mas por motivos teóricos. Pode-se responder fazendo referência a uma representação social, coletiva e dominante, do que é um desempregado, com o risco de observar as distâncias em relação a esta figura instituída, de estar em desacordo com os atributos constitutivos desta concepção de desempregado, de sublinhar uma fragilidade nas normas de referência. Pode-se também responder privilegiando atividades sociais, variadas e reguladas, 


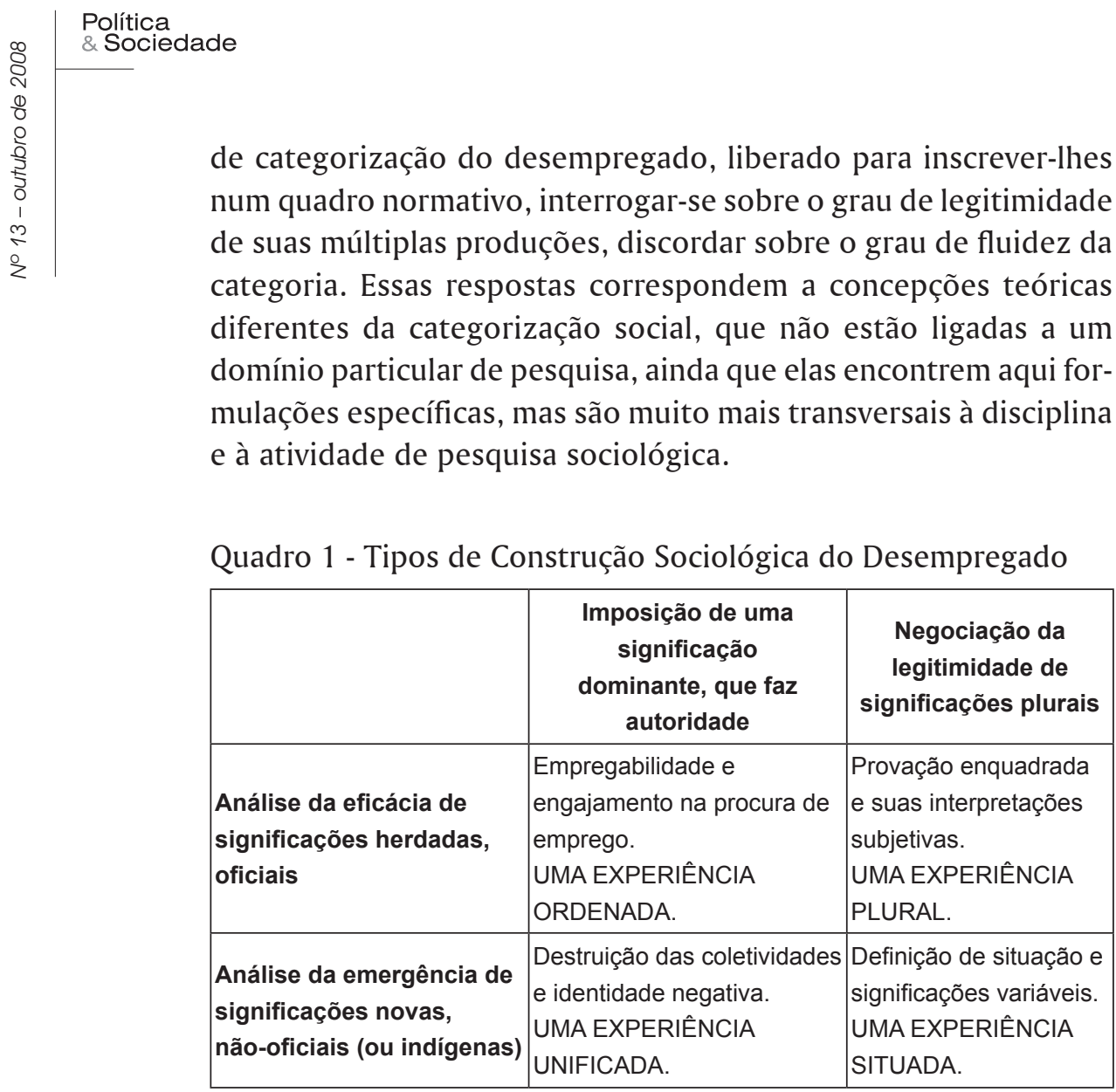

Recebido em 23 de setembro de 2007 Aprovado em 5 de junho de 2008

\section{Referências}

ASTIER, I. Revenu minimum et souci d'insertion. Paris: Desclée de Brouwer, 1997.

BAKKE, E. The unemployed Worker, New Haven: Yale University, 1940.

. The unemployed Man. Londres: Nisbet, 1933.

BALAZS, G. Les facteurs et les formes de l'expérience du chômage. Actes de la recherche en Sciences Sociales, Paris, n. 50, p. 69-83, 1983.

BARTHES, R. Mitologias. Paris: Le Seuil, 1957. 
BASZANGER, I. Les maladies chroniques et leur ordre négocié. Revue Française de Sociologie, Paris, n. 1, p. 3-27, 1986.

BEALES, A. \& LAMBERT, R. Memoirs of the unemployed. Londres: Gollancz, 1934.

BENOIT-GUILBOT, O. La recherche d'emploi: stratégies, qualification scolaire ou professionnelle et qualification sociale. Sociologie du travail, Paris, n. 4, p. 491-506, 1990.

BLANCHET, A. \& GOTMAN, A. L'enquête et ses méthodes: l'entretien, Paris: Nathan, 1992.

CASTEL, R. Les métamorphoses de la question sociale. Une chronique du salariat. Paris: Fayard, 1995.

CHOMBART DE LAUWE, P-H. (dir.) Nous travailleurs licenciés: les effets traumatisants d'un licenciement économique, Paris: UGE, 1976.

CUKROWICZ, H. L'homme en lambeaux: les effets du chômage consécutif à un licenciement économique sur les hommes de 30 à 50 ans. multigr., LASTREE, Université de Lille I, 1981.

DELFINI, C. \& DEMAZIÈRE, D. Le traitement de l'offre d'emploi à l'ANPE. Diversité des logiques d'intermédiation. Travail et Emploi, Paris, n. 81, p. 27-40, 2000.

DEMAZIÈRE, D. Le chômage en crise?. Lille: Universitaires de Lille, 1992a.

. La sociologie française face au chômage. Premiéres réflexions. Cahiers Lillois d'Économie et de Sociologie, Lille, n. 20, p. 41-54, 1992b.

. Placer les chômeurs, réinsérer lês exclus. Évolutions de quelques catégories d'intervention publique. Cahiers Lillois d'Economie et de Sociologie, Lille, n. 21, p. 17-29, 1993.

. La sociologie du chômage, Paris: La Découverte, 1995a. France., 1995b

. Le chômage de longue durée. Paris: Universitaires de . Sociologie du chômage et catégorisations sociales. Trente ans de sociologie, 1966-1996. Institut de Sociologie, Université de Lille I, 24-26 octobre, 1996. 
. 1998. Les chômeurs s'autovalorisent. Chiméres, n. 33, p. 19-37.

. Les actions collectives de chômeurs: une réinvention du chômage?. Projet, Paris, n. 262, p. 27-36, 2000.

. Le fonctionnement local des comités de liaison de l'ANPE. Un dispositif aux significations problématiques. Travail et Emploi, Paris, n. 89, p. 95-112, 2002.

Belin, 2003.

. Le chômage: comment peut-on être chômeur? Paris:

DEMAZIÈRE, D. \& DUBAR, C. Récits d'insertion et mondes socioprofessionnels. Travail et Emploi, Paris, n. 69, p. 55-69, 1996.

. Analyser les entretiens biographiques. L'exemple de récits d'insertion. Paris: Nathan, 1997.

DEMAZIÈRE D. \& PIGNONI M. Chômeurs: du silence à la revolte. Sociologie d'une action collective. Paris: Hachette, 1998.

DUBOIS, $\mathrm{V}$. La vie au guichet. Relation administrative et traitment de la misère. Paris: Économica, 1999.

EISENBERG, P. \& LAZARSFELD, P. The psycological effets of unemployed. Psychological Bulletin, Washington, XXXV, p. 358-389, 1938.

FRÉTIGNÉ, C. Sociologie de l'exclusion. Paris: L'Harmattan, 1999.

GARRAUD, P. Le chômage et l'action publique. Le bricolage “institutionnalisé”. Paris: L'Harmattan, 2000.

GREIMAS, A. Du sens, essais sémiologiques. Paris: Le Seuil, 1970.

GRELL, P. \& WERY, A. Héros obscures de la précarité. Paris: L'Harmattan, 1993.

GUYENNOT, C. Linsertion. Un problème social. Paris: L'Harmattan, 1998.

HYMAN, $\mathrm{H}$. The effects of unemployment: a neglected problem in modern social research. In: MERTON, R.; COLEMAN, J. \& ROSSI, P. (ed.). Qualitative and quantitative research. Papers in honor of Paul F. Lazarsfeld. New York: The Free, 1979.

JAHODA, M. The impact of unemployment in the 1930s and the 1970s. Bulletin of the British Psychological Society, London, 32, p. 309-314, 1979. 
JELLAB, A. Le travail d'insertion en mission locale. Paris: L'Harmattan, 1997.

KOMAROVSKY, M. The unemployed man and his family. New York: Octagon, 1940.

LAGRÉE, J. \& LEW FAI, P. Jeunes et chômeurs. Paris: CNRS, 1989.

LAZARFELD, P.; JAHODA, M. \& ZEISEL, H. Les chômeurs de marienthal. Paris: Minuit, 1981.

LEDRUT, R. Situation du chômage et analyse sociologique de situation. Cahiers internationaux de sociologie, Liège, n. 1, p. 43-65, 1961a.

. 1961b. Les chômeurs: faiblesse sociale et sentiment de faiblesse. Revue française de sociologie, Paris, 2, p. 177-195, 1961b.

LEDRUT, R. Sociologie du chômage. Paris: PUF, 1966.

LE MOUËL, J. Le chômage des jeunes: des 'vécus' trés différents. Sociologie du travail, Paris, n. 2, p. 163-172, 1981.

ORWELL, G. Le quai de Wigan. Paris: Ivrea, 1937.

PAUGAM, S. Introduction: la constitution d'un paradigme. In: PAUGAM, S. (dir.). Lexclusion. L'état des savoirs. Paris: La Découverte, 1996a.

PAUGAM, S. Les sciences sociales face à l'exclusion. In:

(Dir.), op. cit., p. 565-577, 1996b.

PIGNONI, M. Conditions de vie et perception subjective d'une expérience prolongée de chômage. In: BOUILLAGUET, P. \& GUITTON, C. (texts réunis par), Le chômage de longue durée. Comprendre, agir, évaluer. Paris:Syros/Alternatives, 1992.

PILGRIM TRUST. Men without work. Cambridge University, 1938.

PISSARD, F. ; PONCELET, M. \& VOISIN, M. Vivre en chômage. Linstallation des jeunes sans emploi dans la vie adulte. Revue Française de Sociologie, Paris, n. 4, p. 573-590, 1990.

PUGLIESE, E. Socio-économie du chômage. Paris: L'Harmattan, 1996. 
RAGIN, C. Introduction: Cases of 'what is a case?'. In: RAGIN, C. \& BECKER, H. (ed.). What is a case? Exploring the Foudations of Social Inquiry. Cambridge University, p. 1-17, 1992.

RICOEUR, P. Temps et récit. 2. La configuration dans le récit de fiction. Paris: Lê Seuil, 1984.

RIFAÏ, N. Le chômage et le chômeur de longue durée. Les médiateurs de l'emploi à l'épreuve des faits. Paris: L'Harmattan, 1996.

SCHEHR, S. La vie quotidienne des jeunes chômeurs. Paris: PUF, 1999. . Processus de singularisation et formes de socialisation de la jeunesse. Lien Social et Politiques-RIAC, n. 43, p. 49-58, 2000. SCHNAPPER, D. Rapport à l'emploi, protection sociale et status sociaux. Revue Française de Sociologie, Paris, XXX-1, p.3-29, 1989. SCHNAPPER, D. Lépreuve du chômage. Paris: Gallimard, 1994. . La comprensión sociologique. Démarche de l'analyse typologique. Paris: PUF, 1999.

SIMONIN, B. Diversité persistante des conduites de recherche d'emploi. Pages du Centre d'Études de l'Emploi, n. 39, 2000.

WILLMANN, C. Lidentité juridique du chômeur. Paris: D. et de Jurisprudence, 1998.

WUHL, S. Du chômage à l'exclusion? Létat des politiques, l'apport des experiences. Paris: Syros-Alternatives, 1991.

ZAWADSKI, B. \& LAZARSFELD, P. The psychological consequences of unemployment. Journal of Social Psychology, n. 6, p. 224-251, 1935.

ZEISEL, H. The Vienna years. In: MERTON, R.; COLEMAN, J. \& ROSSI, P. (Ed.). Qualitative and quantitative research. Papers in honor of Paul F. Lazarsfeld. New York: The Free, 1979. 